\title{
Review \\ Recent Developments and Challenges on Beam Steering Characteristics of Reconfigurable Transmitarray Antennas
}

\author{
Qasim Ali ${ }^{1}$ D, Waseem Shahzad ${ }^{1}$, Iftikhar Ahmad ${ }^{1}$, Shozab Safiq ${ }^{1}$, Xi Bin $^{2}$, Syed Muzahir Abbas ${ }^{3}$ \\ and Houjun Sun $1, * \mathbb{D}$
}

1 Beijing Key Laboratory of Millimeter-Wave and Terahertz Wave Technology, Beijing Institute of Technology, Beijing 100081, China; qasimali@bit.edu.cn (Q.A.); waseem@bit.edu.cn (W.S.); iftikhar.roghani@bit.edu.cn (I.A.); shozabshafiq@gmail.com (S.S.)

2 School of Electronics and Communication Engineering, Sun Yat-Sen University, Guangzhou 510275, China; xibin@mail2.sysu.edu.cn

3 School of Engineering, Faculty of Science and Engineering, Macquarie University, Sydney, NSW 2109, Australia; syed.abbas@mq.edu.au

* Correspondence: sunhoujun@bit.edu.cn

check for updates

Citation: Ali, Q.; Shahzad, W.; Ahmad, I.; Safiq, S.; Bin, X.; Abbas, S.M.; Sun, H. Recent Developments and Challenges on Beam Steering Characteristics of Reconfigurable Transmitarray Antennas. Electronics 2022, 11, 587. https://doi.org/ 10.3390/electronics 11040587

Academic Editor: Sotirios K. Goudos

Received: 5 January 2022

Accepted: 10 February 2022

Published: 15 February 2022

Publisher's Note: MDPI stays neutral with regard to jurisdictional claims in published maps and institutional affiliations.

Copyright: () 2022 by the authors. Licensee MDPI, Basel, Switzerland. This article is an open access article distributed under the terms and conditions of the Creative Commons Attribution (CC BY) license (https:/ / creativecommons.org/licenses/by/ $4.0 /)$.

\begin{abstract}
This paper highlights recent developments and challenges on beam steering characteristics of reconfigurable transmitarray antennas. It introduces the operating principle of beam forming/beam steering high gain transmitarray antennas to enable the user to opt for economical and high performance solutions. A transmitarray antenna typically consists of a source antenna and a phase transformation structure. The incident waves generated from the source antenna is tilted using the phase transformation structure in a desired direction to steer the beam. Moreover, the phase transformation structure alters the incident wavefront to a plane wavefront using phase change characteristics. In order to steer a beam to a specific desired angle, it can be divided into two methods. There is a method of applying a transmitarray with a variable transmission phase change or a method of changing the shape of the wavefront of the source antenna. This type of beam forming/beam steering high gain antenna has been mainly studied from the point of view of high efficiency, low profile, and low cost. Several solutions of transmitarray unit cells have been presented in the literature, using PIN diodes, varactors, MEMS switches, and microfluids enable electronics to realize reconfigurable characteristics of transmitarray antennas. This paper analyzes the characteristics of various beam steering high gain reconfigurable transmitarrays (RTA) and highlights the future opportunities and challenges of the structure design for transmitarray antennas. This paper also highlights the challenges and gaps in terahertz and optical frequencies related to future work due to the structure complexity and lack of components' availability. Moreover, the challenges and limitations related to multi-bit structures and dual-band requirements are presented.
\end{abstract}

Keywords: reconfigurable transmitarray; beam steering; beamforming; PIN diodes; varactor; MEMS; dual-band transmitarray; multi-bit transmitarray

\section{Introduction}

The high gain beam steering antennas are widely used in 5G wireless mobile communications, radio frequency (RF) wireless power transmission, and satellite communications [1-3]. In order to obtain high gain and beam steering characteristics, traditionally, antennas of the same type as phased array antennas, reflectarray antennas, and parabolic antennas have been designed [4-6]. However, these types of antennas have some disadvantages despite their excellent characteristics since the parabolic antenna and the dielectric lens antenna have a curved shape (i.e., non-planar structures), are expensive, and difficult to manufacture. In addition, a planar phased array antenna with high gain characteristics in the millimeter-wave band may have a complex feeding structure with losses that might influence the antenna's overall radio performance. 
Transmitarrays also considered as lens arrays or lenses were first presented in [7] by achieving control on EM waves. A lens antenna was proposed in [8] with a characteristic change that can control the wavefront of transmitted and reflected electromagnetic waves. Using a simple microwave lens antenna to attach two patch antennas with a center probe to transfer electromagnetic (EM) energy, the configuration was able to perform characteristics of scanning and focusing of an EM beam by microwave lens antenna. Microwave lenses obtained more interest when researchers achieved a better understanding of planar antennas and microstrip patch antennas [9]. Transmitarray uses a simple Snell's law for working operation, which causes a narrow bandwidth and time-consuming structures. All dielectric and all metal structures are adopted to improve their capabilities for these disadvantages. All dielectric structures are widely utilized for transmitarrays due to their high transmittance, low cost, easy fabrication, and lightweight qualities [10-12]. TA structures develop with all dielectric materials, while a genetic algorithm (GA) and practical swarm optimization algorithm (PSO) are applied to optimize each pillar unit cell $[13,14]$. The integrated optimization strategy increases design reliability while freeing up human effort and time. Furthermore, in order to achieve wideband characteristics, the optimizing goal is to design a rectangular area to accommodate the source antenna's shifting phase center. As we develop all dielectric TA designs, 3D printing technology can easily fabricate designs and provides advantages of being lightweight, low cost, and easy to fabricate.

All dielectric TAs have some disadvantages as compared to all metal TAs such as high profile, low machining accuracy, and electromagnetic properties of high power microwave applications [15]. Furthermore, for some applications, TAs are utilized in harsh working environments such as space. In these conditions, TAs without dielectric materials adapt to environmental conditions better than dielectric materials and reduce fabrication cost. Dielectric materials are not appropriate for high frequencies, whereas metals have lowfrequency electromagnetic effects on high frequencies. Many studies have been proposed in the literature for all metal transmitarrays [16-19]. Most of them adopt the multilayer method to obtain 360 degrees phase shift and low losses amplitude. Many improvements deliver for all metal TAs but their bandwidth is still relatively low.

The transmitarray (TA) has attracted more and more interest from researchers due to its low profile, affordable cost, lower losses, low design complexity, and ease of fabrication. These have become popular solutions due to their remarkable applications, for instance, in biomedical systems (Brain and Breast Cancer Detection), civil and military radar systems, imaging systems, satellite communications, direct broadcasting services, and 6G/5G communication systems, etc. [20-26]. Transmitarrays (TAs) are primarily composed of several discrete unitary elements, and special feed sources (horn antenna, microstrip patch antennas, or other UWB antennas) are used to illuminate EM waves. They also used multilayer frequency selective surfaces, meta-materials, and metasurfaces [27-29]. There are various dynamic technologies exploited to enable the reconfigurable characteristics of TAs. Reconfigurable features perform electronic beam forming or beam steering, frequency tuning, and the control of polarization by solid-state electronics devices such as using PIN diodes [30-32], varactors [33], MEMS (micro-electromechanical systems) switches [34], tunable dielectric substance liquid crystals [35,36], microfluidic systems [37], and graphene [38]. All these components have dynamic performance with respect to their advantages and disadvantages; PIN diodes and varactors are commonly used in solid-state devices available for lower radio frequencies up to $40 \mathrm{GHz}[39,40]$. In recent years, substantial advancements have been made in the development and implementation of reconfigurable technology for antennas and other solid-state devices.

Versatile communication systems and radars have upsurged the demand for reconfigurable devices and components. MEMS switches are reliable in operation but not an economical solution as compared to the diodes. However, these face challenges of wear and tear of the mechanical part. Therefore, liquid crystal and graphene are exotic solutions for high frequencies, particularly for terahertz (THz) frequencies. There are many applications of liquid crystal- and graphene-based transmitarrays reported in the literature [41-43]. 
They are feasible for phase integration, their small size and low biasing complexity at lower to higher frequencies. Due to their advantage of being able to vary the transmission phase change freely, most of the beam forming/beam steering reconfigurable transmitarrays are designed by the former method. However, there is a disadvantage of the overall radio performance of the transmitarray antenna that may deteriorate due to its complexity of implementation or the additional loss of active elements. The latter method structurally changes the wavefront shape of the source antenna electrically or mechanically and has the advantage of structurally fixing the TA. However, there is a disadvantage of a large motor for arrays as mentioned in [44-48].

Significant research has been conducted in recent years [49-53]. A transmitarray antenna has been implemented with a source antenna (horn, microstrip patch antenna) and a planar array. The working principle of a transmitarray antenna uses a high transmittance and a transmission phase change characteristic of more than 360 degrees to control the wavefront of the source antenna. This type of transmitarray antenna is a high gain antenna and is beam forming, beam steering, and multi-beam [54-56]. It is designed as a beam control system such as PIN diodes, varactors, MEMS systems, and microfluids. These reconfigurable devices can be used in many applications. In order to perform beam forming/beam steering in the desired direction, it can be roughly divided into two methods. The total wavefront of the transmitarray antenna can be calculated as the sum of the wavefront of the source antenna and the wavefront of the plane wave passing through the transmitarray. This point is used to implement beam steering by a transmitarray with variable transmission phase change or when the wavefront shape of the source antenna is applied.

This paper is written in the following structure. Section 2 describes the beam forming/beam steering principle and characteristic analysis of a transmission antenna using a TA, and its relation to the aperture efficiency, which is an important performance indicator of the transmitarray antenna. In Section 3, the operating principle and results of various types of reconfigurable transmitarrays are presented, focusing on operation and devices that provide dual-band operation, dual-polarization capability, frequency agility, and other unique features. Section 4 discusses the future opportunities and challenges in the structure and characteristics of various beam steering high gains reconfigurable transmitarrays (RTAs). Future challenges and the scope of beam steering transmitarrays are discussed in Section 5. Finally, the conclusion is presented in Section 6.

\section{Beam Steering/Beam Forming Principle of Transmitarray}

The transmitarray antenna is an antenna that is capable of modifying the radiation pattern of a directional antenna such as a patch antenna or a horn antenna. A transmitarray has the capability of adjusting the wavefront of the source antenna and the incident wave. By using a structure that can adjust the size and phase of the incident wave, the transmission antenna can be used in various fields such as beam steering, beam focusing, and polarization control. Figure 1 shows a typical radiation model of a transmission antenna composed of a source antenna and a transmitarray. A transmitarray is formed by a feed, which is labeled as a source antenna where the source antenna is placed at a distance $\mathrm{F}$ from transmitarray. Focal distance $(\mathrm{F})$ is calculated as a tradeoff between spillover losses and an increase in gain, aperture efficiency, and other parameters. The source antenna illuminated by incident wave to the first part of the array is called the receiver. The receiver is directly connected to group of phase shifters to control the beam wave front in the required direction. The other end of the phase shifters are coupled with a transmitter layer, which produces a phase shift in the incident wave that works in transmitter mode. The phase shifter of each unit cell provides $\gamma \mathrm{n}$ path difference to the source point to obtain the desired scan angle $\theta$. As shown in Figure 1, the direction of the incident wave is determined by radiation controlled by the transmission phase of the transmitarray. Transmitarrays are generally composed of several resonant unit cells with a spatial periodicity that forms a planar arrangement. 


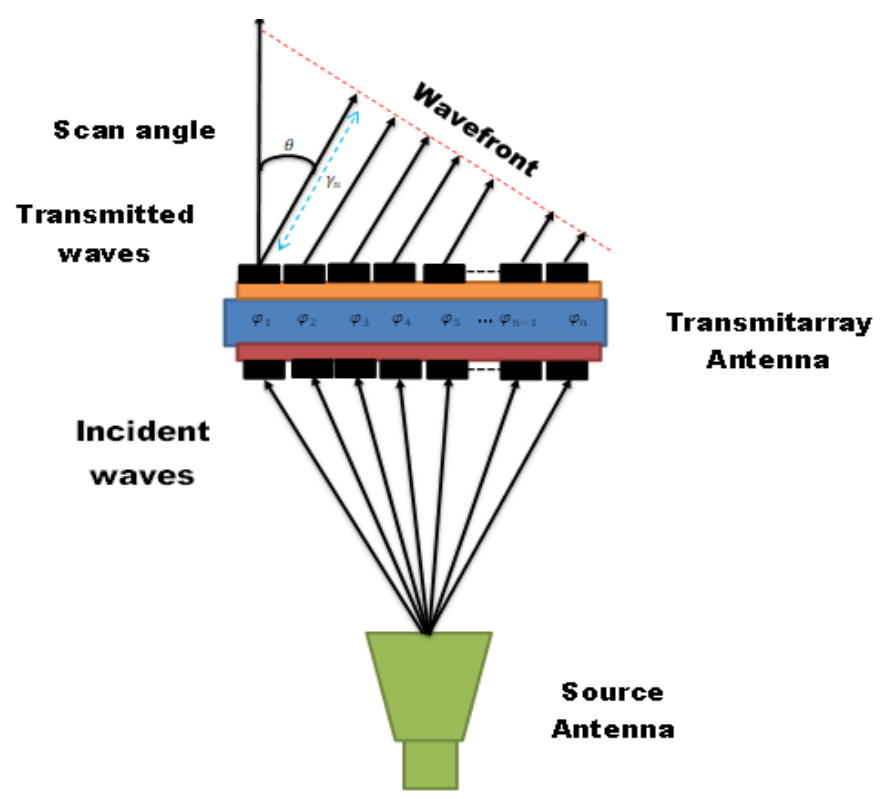

Figure 1. Generic radiation model of transmitarray antenna.

The principle of beam forming/beam steering transmitarrays is reported in [57-62]. There are incident EM waves generated from a feed source that passes through a transmitarray made up of nth $(\mathrm{n}=0,1, \ldots)$ elements of periodicity of "a" and produces phase change $\varphi_{\mathrm{n}}$ shown in Equation (1).

$$
\varphi_{\mathrm{n}}=\mathrm{k}_{\mathrm{o}} \mathrm{n} \Delta \mathrm{s}+\varphi_{0}
$$

where $\mathrm{k}_{\circ}=\frac{2 \pi}{\lambda_{0}}$ is the propagation constant of the free space-waves. $\Delta \mathrm{s}$ is the path difference between the nth and $(n+1$ th) elements after they pass through the transmitarray. $\Delta s$ is defined here for the deflection angle $\theta$ of the transmitted wave with element dimensions a that is the path difference with the deflection angle $\Delta \mathrm{s}=\mathrm{a} \cdot \sin \theta$. Now we can write the phase change as $\varphi_{\mathrm{n}}=\varphi_{\mathrm{n}+1}-\varphi_{\mathrm{n}}$.

$$
\begin{gathered}
\Delta \varphi=\mathrm{k}_{\circ} \Delta \mathrm{s}=\frac{2 \pi}{\lambda_{0}} \cdot \mathrm{a} \cdot \sin \theta \\
\sin \theta=\frac{\lambda_{0}}{2 \pi \mathrm{a}} \cdot \Delta \varphi
\end{gathered}
$$

Equations (2) and (3) demonstrate that if we define the deflection angle $\theta$, we can calculate the phase change $\Delta \varphi$ from Equation (2). Thus, both equations show inter-dependent relations for each other [63]. Similarly, the design and implementation of beam switching in arrays using a butler matrix have also been reported [64-66].

Transmitarray unit cells are usually designed based on microstrip patches, metamaterials $[67,68]$, and frequency selective surfaces (FSS) $[69,70]$. The microstrip patch metasurface of the unit cell and its permeation characteristics are shown in [71]. The unit cell comprises of four dielectrics and five circular metal patches, and the equivalent circuit model can be expressed by series inductance and parallel capacitance in the passband. The transmission characteristics of the metasurface can be controlled by the radius (a) of the metal circular patch and the transmittance and transmission phase of the circular microstrip patch array transmitarray at $5.8 \mathrm{GHz}$. In this case, the size $(\mathrm{W})$ of the square unit cell is $20 \mathrm{~mm}\left(0.38 \lambda_{0}\right)$, the dielectric constant $(\varepsilon r)$ and thickness (h) of the dielectric substrate are 2.2 and $3.2 \mathrm{~mm}$, respectively. From $1 \mathrm{~mm}$ to $9.1 \mathrm{~mm}$, a transmittance of 0.8 or more and a change in transmission phase of about 400 degrees can be obtained. A high gain transmission antenna using a metasurface composed of $10 \times 10$ circular patch array unit cells is presented. The total size of the transmitarray is $200 \mathrm{~mm}$ (about $4 \lambda_{0}$ ), and the distance between the source antenna and the metasurface is $50 \mathrm{~mm}$ (about $1 \lambda_{0}$ ). 
The total wavefront of the transmitarray antenna can be conceptually expressed as the sum of the wavefront of the source antenna and the transmission phase of the transmitarray, as illustrated in Figure 2. When the focal source antenna and transmitarray antenna are fixed for phase implementing high gain and shape of the wavefront, a straight line is demonstrated in Figure 2a. The focal source antenna is fixed, whereas phase change is implemented by an active transmitarray in Figure $2 b$. A high gain variable phase change is achieved in this scenario by changing the wavefront of the active transmitarray. It is illustrated in Figure 3 that the wavefront of the transmitarray antenna is fixed through the change in the wavefront shape of the source antenna using the phase transformation surface that helps to implement the change of phase and achieve the high gain steering transmitarray. Aperture efficiency is an important performance indicator of a transmitarray antenna. Aperture efficiency $\left(\eta_{a}\right)$ is defined in terms of the taper efficiency $\left(\eta_{t}\right)$, spillover efficiency $\left(\eta_{s}\right)$, polarization efficiency $\left(\eta_{\text {pol }}\right)$, transmission efficiency $\left(\eta_{\text {tran }}\right)$, phase efficiency $\left(\eta_{p h}\right)$, and random surface as in Equation (4). It can be calculated as the product of the error efficiency $\left(\eta_{r}\right)[72]$.

$$
\eta_{a}=\eta_{t} . \eta_{s} . \eta_{\text {pol }} . \eta_{\text {tran }} \cdot \eta_{p h} \cdot \eta_{r}
$$

Here, the efficiencies that mainly affect the aperture efficiency of the transmitarray antenna are the taper efficiency and the spillover efficiency. These two efficiencies are determined by the size and spacing of the source antenna and the metasurface. Taper and spillover efficiencies are related to the uniformity and amount of power reaching the metasurface from the source antenna, respectively, and are calculated by Equations (5) and (6).

$$
\begin{gathered}
\eta_{t}=\frac{\eta_{a}}{S} \frac{\left|\int E(x, y)^{2} \cdot d S\right|^{2}}{\int\left|E(x, y)^{2} d S\right|} \\
\eta_{s}=\frac{\int\left|E(x, y)^{2} d S\right|}{P_{\text {rad }}}
\end{gathered}
$$

where $S$ and $P_{\text {rad }}$ are the area of the metasurface and the radiation power of the source antenna, respectively. It is vital to determine the source antenna, the distance between the source antennas and the plane array (F), and the size (D) of the transmitarray to optimize the aperture efficiency of the transmitted antenna using the TA.

When the distance between the source antenna and the plane array is short, the spillover efficiency is high but the taper efficiency is low. Conversely, if F becomes longer, taper efficiency is high but spillover efficiency is lower. In addition, as the size of the transmitarray increases, the spillover efficiency is high but the taper efficiency decreases. Therefore, to maximize the aperture efficiency of the transmit antenna, it is necessary to optimize F/D. Maximum numerical aperture efficiency and the optimum gain of the source antenna following various F/D are shown in [42]. In this case the gain of the source antenna has become relatively low, the maximum value of the aperture efficiency decreases, but the distance $\mathrm{F}$ with maximum efficiency is reduced and a low-profile transmitarray antenna can be designed. In addition, a source antenna with a high gain may be applied to secure the maximum aperture efficiency, for example, when a patch antenna having a gain of $7.5 \mathrm{dBi}$ is applied to a transmission antenna as a source antenna, the maximum aperture efficiency is about $62 \%$, and F/D can be designed to 0.2 . 


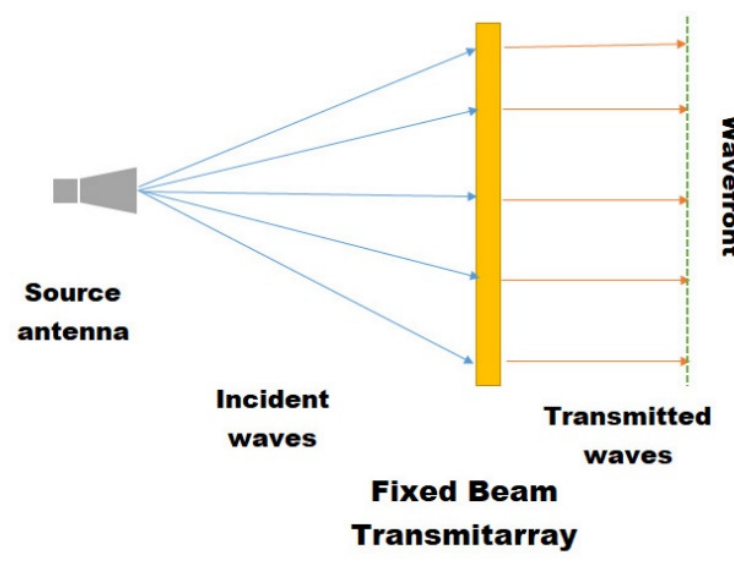

Fixed phase of

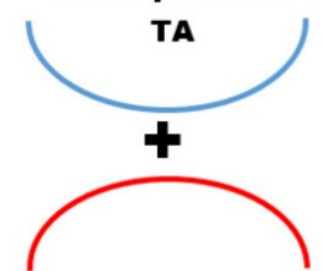

Fixed Phase of

Source Antenna

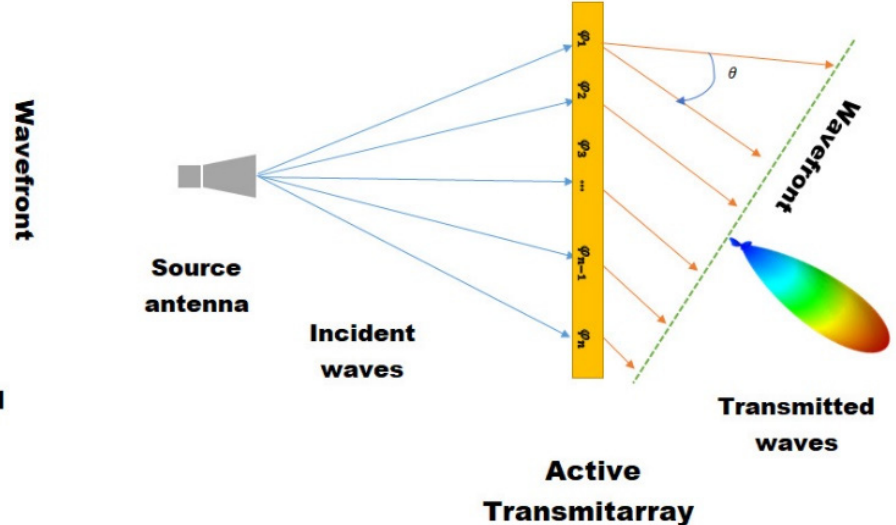

Variable phase of

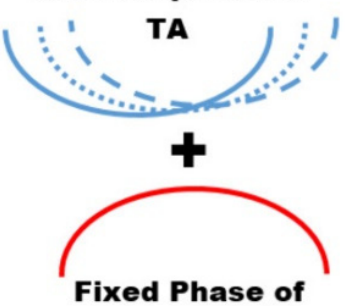

Source Antenna

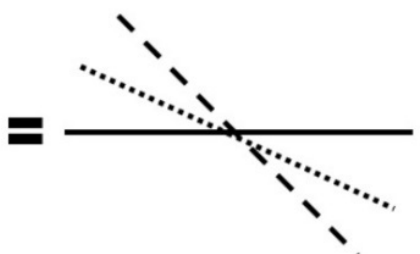

Beam-Steering Wave Front of TA

(a)

(b)

Figure 2. Conceptual diagram of the wavefront of (a) fixed beam transmitarray and fixed source antenna (b) active transmitarray with fix source and variable phase shift of TA.

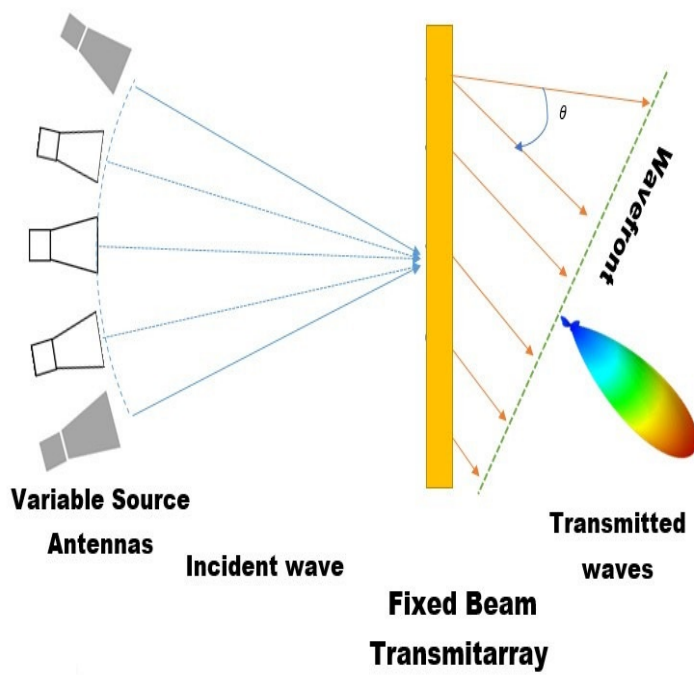

(a)

\section{Fixed phase of}

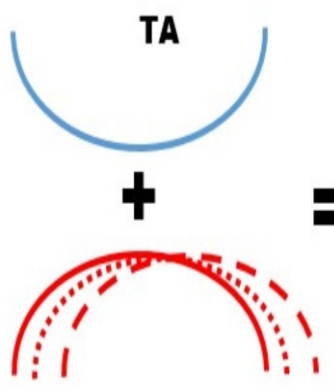

Variable Phase of

Source Antenna

\section{Beam-Steering \\ Wave Front of TA}

(b)

Figure 3. (a) Conceptual diagram of the wavefront of fixed beam transmitarray and variable source antenna; (b) phase variation concept of fixed transmitarray and variable source antenna.

\section{Beam Steering/Beam Forming Using Reconfigurable Components}

Several studies are available in the literature [73-80] to demonstrate the operations and functions of transmitarray beam steering. These are realised by utilizing different reconfigurable devices, materials, element designs, and operational parameters. However, every structure needs a requisite to obtain the beam steering/beam forming of the transmitarray antenna. Each transmitarray unit cell must acquire a transmission phase that can be 
tuned (varied) up to 360 degrees. Moreover, the transmission coefficient should remain constant throughout the operational bandwidth. This section focuses on demonstrating the electronically reconfigurable beam of transmitarray, transmission phase distribution on the transmitarray surface, and the phase shift of each unit cell. Reconfigurable beam steering can be achieved with different techniques. The most prominent one is electronic control accomplished, which is achieved by loading one or more active devices into the resonant elements designed on the unit cell such as (PIN diodes, varactors, and MEMS switches). Other techniques are on the utilization of tunable materials (liquid crystal, microfluidic systems). There is a detail Summary of beam steering reconfigurable transmitarrays with PIN diodes is presents in Table 1.

\subsection{PIN Diodes}

The author of [73] proposed a 2-BIT electronically reconfigurable beam steering transmitarray unit cell. A reconfigurable transmitarray unit cell is composed of six metal layers. The transmitter patch has an $\mathrm{O}$ shape slot, and two PIN diodes are mounted to the microstrip patch element. The receiver patch has etched on another $\mathrm{O}$ slot patch connected to a transmitter patch with a metallic via that transfer electromagnetic energy to the transmitter. This unit cell achieves $10.1-12.1 \% 3 \mathrm{~dB}$ transmission bandwidth. This paper is further extended in $[74,75]$ to validate the array parameters of this technique. There are two transmitarrays of $14 \times 14$ and $20 \times 20$, reported as switchable circular and linear polarization. These are 1-bit and 2-bit phase resolution variable (tunable) unit cells. There are two and four PIN diodes mounted that allow transmission phase control for each design, respectively. The 1-bit prototype reconfigurable unit cell's measured gain is $20.8 \mathrm{dBi}$ with a $3 \mathrm{~dB}$ transmission bandwidth of $14.6 \%$ at $29 \mathrm{GHz}$. The 2-bit design has a measured gain of $19.8 \mathrm{dBi}$ with a $3 \mathrm{~dB}$ bandwidth of $16.2 \%$ at $29 \mathrm{GHz}$.

Moreover, a novel reconfigurable Yagi-Vivaldi transmitarray structure was reported in $[76,77]$ for beam steering of the transmitarray at Ku-band. This reconfigurable transmitarray (RTA) primarily focused on a wide bandwidth and beam scanning at Ku-band. The RTA unit cell contains a tightly coupled microstrip. A Vivaldi antenna based on the transmitter and a Yagi antenna structure etched on it behaves as a transmitter. A pair of anti-parallel diodes are mounted on a slot-line to the microstrip phase shifter to obtain $180^{\circ}$ phase shift with the current reversal mechanism shown in Figure 4 . It achieves $14 \% 1 \mathrm{~dB}$ bandwidth of a reconfigurable transmitarray with peak gain $22.3 \mathrm{dBi}$ at $13.6 \mathrm{GHz}$. The RTA realized $25.6 \%$ aperture efficiency with \pm 60 degrees scan angle for both E-plane and H-plane. Two novel linearly polarized reconfigurable design transmitarrays have been investigated with PIN diode at $\mathrm{Ku}$-band in [78,79]. An asymmetric dipole element PIN diode-based reconfigurable transmitarray is presented in [79]. This novel design has been investigated as a 1-bit dual-band linearly polarized reconfigurable transmitarray at $\mathrm{Ku}$-band, as shown in Figure 5. This element has an active dipole for the receiver and an asymmetric passive dipole for the transmitter 1-bit transmission phase shift, obtained by integrating two diodes on an active patch in the reverse direction with the current reversal mechanism. To reduce the impact of diode resistance and improve insertion loss, two parasitic bypass dipoles alongside the main patches can be added. The dual-polarization parameter is realized by orthogonal interconnecting for the transmitter and receiver. A $10 \times 10$ elements array is designed, manufactured, and tested. It achieves measured aperture efficiency of $22.6 \%$ with a peak gain of $18.3 \mathrm{~dB}$ at $12.2 \mathrm{GHz}$. The 2D beam steering feature correspondence realized in a test environment with a scanning angle covers \pm 50 degrees. The maximum measured E-Plane and H-plane losses are $2.9 \mathrm{~dB}$ and $3.5 \mathrm{~dB}$, respectively, as shown in Figure $5 \mathrm{c}$. 


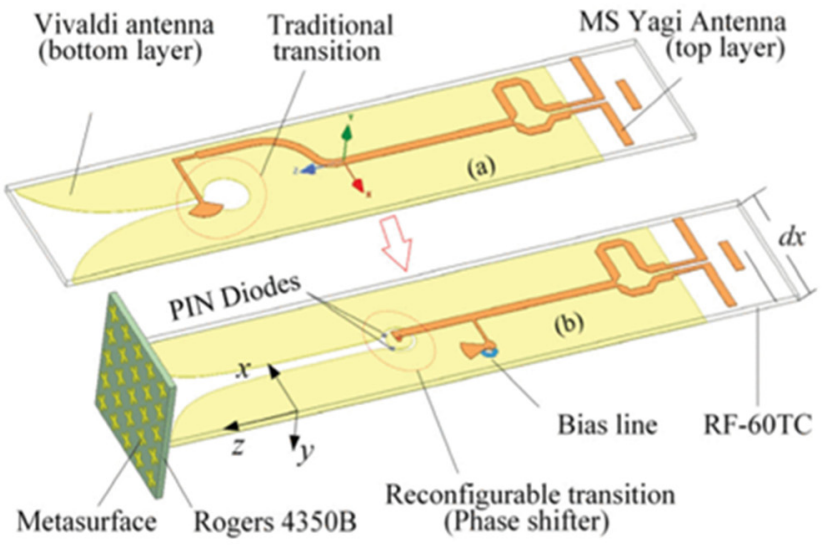

(a)

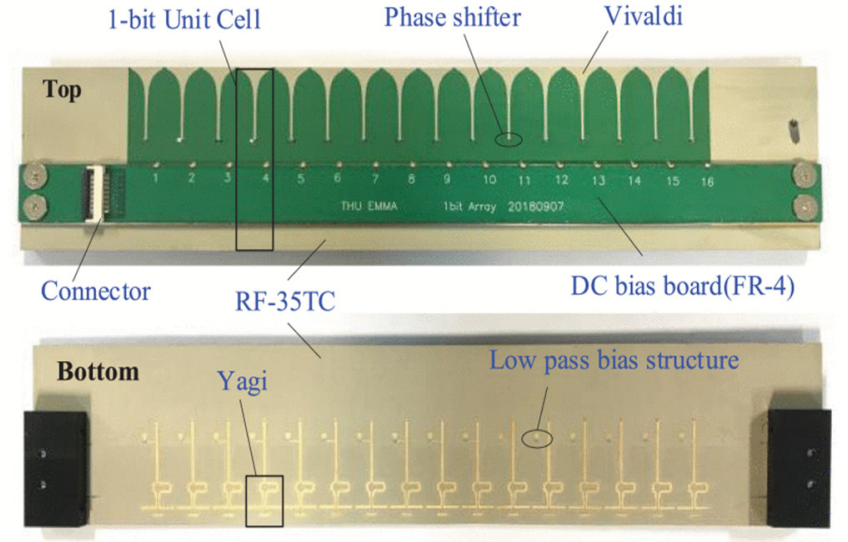

(b)

Figure 4. (a) Geometry of Vivaldi reconfigurable transmitarray with WIAM metasurface; (b) fabricated $1 \times 16$ subarray prototype (reprinted with permission of [76]. Copyright 2021 Xiao, Y., et al.).

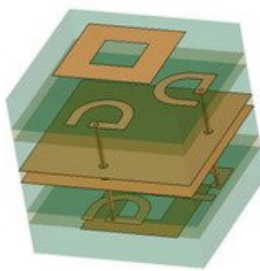

(a)

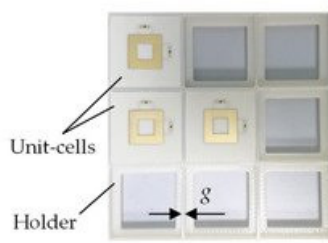

(d)

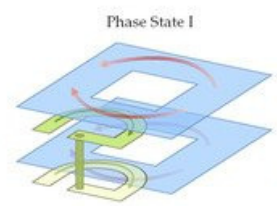

(b)

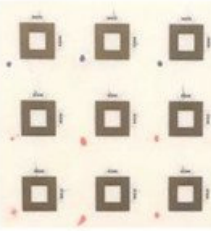

(e)

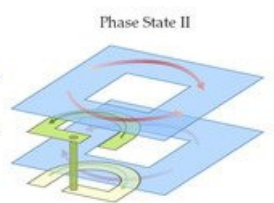

(c)

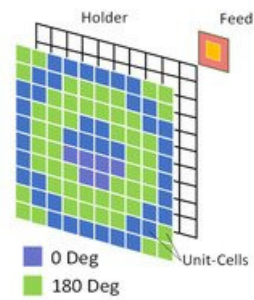

(f)
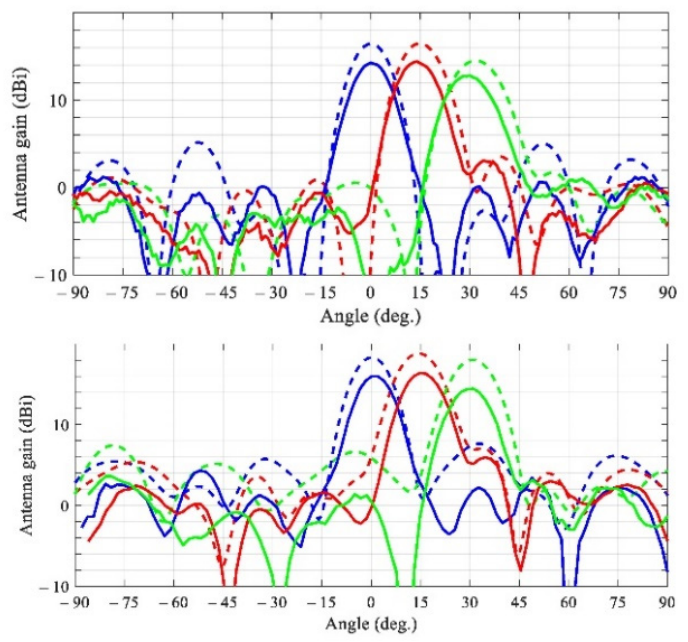

(g)

Figure 5. Geometry of $3 \times 31$ bit RTA element with biasing circuit; (a-f) exploded view, top view; (g) measures radiation pattern of E-plane and H-plane, respectively (reprinted with permission of [80]. Copyright 2021 Kozlov, D., et al.).

Another novel C-band design of a transmitarray is discussed in [80], and some other applications of this array are explored in [80-82]. A C-band square ring patch with proximity coupled U-shape resonator transmitarray is proposed. A prototype of a 1-bit beam steering $10 \times 10$ transmitarray with performance is presented. A prototype of a square ring patch with a proximity coupled U-shape resonator with good/bad effects is also demonstrated. The dual-polarized beam scanning effect is experimentally verified in the test setup. The maximum measured gain of the proposed transmitarray is $12 \mathrm{dBi}$, corresponding to maximum scan loss that reaches $2 \mathrm{~dB}$ with a scan angle of \pm 30 degrees.

Furthermore, a novel architecture of a reconfigurable coupling slot transmitarray is mentioned in [83]: a prototype of a 1-bit electronically reconfigurable transmitarray for $\mathrm{Ku}$-band. Two orthogonal $\mathrm{H}$-shape slots were integrated on patches that act as transmitter and receiver, respectively. Electromagnetic energy was transmitted by coupling a transmit line in between slot patches. Diodes were mounted on the coupling line to realize the electronic phase control in an anti-parallel direction to produce $180^{\circ}$ phase difference. The oblique incidence performance of the elements was maintained by sub-wavelength element spacing $\lambda_{0} / 3$. A $16 \times 16$ element $12.5 \mathrm{GHz}$ reconfigurable transmitarray was designed and tested. The maximum gain of $17.0 \mathrm{dBi}$ corresponds to an aperture efficiency of $14.0 \%$ 
presented in experimental results. The H-shape coupling slot transmitarray realizes a beam scanning angle within \pm 50 degrees for $\mathrm{E}$ - and H-planes. The $3 \mathrm{~dB}$ gain bandwidth retains $9.6 \%$ in the measured results.

Table 1. Summary of beam steering reconfigurable transmitarrays with PIN diodes.

\begin{tabular}{|c|c|c|c|c|c|c|c|c|c|}
\hline Ref. & $\begin{array}{l}\text { Unit Cell } \\
\text { Technique }\end{array}$ & $\begin{array}{l}\text { Phase } \\
\text { Control } \\
\text { Device }\end{array}$ & $\begin{array}{l}\text { Frequency } \\
(\mathrm{GHz})\end{array}$ & Polarization & $\begin{array}{l}\text { Phase } \\
\text { Range }\end{array}$ & Gain (dBi) & $\begin{array}{l}\text { Aperture } \\
\text { Efficiency } \\
(\%)\end{array}$ & $\begin{array}{l}\text { Band } \\
\text { Width }\end{array}$ & $\begin{array}{c}\text { Beam Scanning } \\
\text { Capacity }\end{array}$ \\
\hline [32] & $\begin{array}{c}\text { PCB } \\
\text { stacked } \\
\text { patch }\end{array}$ & PIN diode & 5.4 & $\mathrm{LP}, \mathrm{CP}$ & 1-B1T & 17 & 28.5 & 8.5 & $\pm 50^{\circ} \mathrm{E}$ and $\mathrm{H}$ plane \\
\hline [73] & $\begin{array}{l}\text { O-U slot } \\
\text { patches } \\
\text { double }\end{array}$ & PIN diode & 29 & $\mathrm{CP}$ & 1-B1T & 28.5 & 9.5 & $14.6 \%$ & $\pm 60^{\circ} \mathrm{E}$ and $\mathrm{H}$ plane \\
\hline$[74]$ & $\begin{array}{l}\text { O-slot } \\
\text { patches }\end{array}$ & PIN diode & 29 & LP & 2-B1T & 19.8 & 15.9 & $16.2 \%$ & $\pm 60^{\circ} \mathrm{E}$ and $\mathrm{H}$ plane \\
\hline [76] & $\begin{array}{l}\text { microstrip } \\
\text { Vivaldi }\end{array}$ & PIN diode & 13.6 & LP & 1-B1T & 22.3 & 25.6 & $\begin{array}{c}1.9 \% \\
(1-\mathrm{dB})\end{array}$ & $\pm 40^{\circ} \mathrm{E}$ and $\mathrm{H}$ plane \\
\hline [79] & $\begin{array}{l}\text { coupled } \\
\text { slot }\end{array}$ & PIN diode & 12.5 & LP & 1-B1T & 17 & 14 & $9.6 \%$ & $\pm 50^{\circ} \mathrm{E}$ and $\mathrm{H}$ plane \\
\hline [80] & $\begin{array}{l}\text { Square ring } \\
\text { patch }\end{array}$ & PIN diode & 5.75 & $\mathrm{CP}$ & 1-BIT & 14 & - & $2.5 \%$ & $\pm 30^{\circ} \mathrm{E}$ and $\mathrm{H}$ plane \\
\hline [83] & $\begin{array}{l}\text { H and I } \\
\text { shape } \\
\text { coupling } \\
\text { slot }\end{array}$ & PIN diode & 12.5 & $\mathrm{LP}$ & 1-BIT & 17 & 14 & $9.6 \%$ & $\pm 50^{\circ} \mathrm{E}$ and $\mathrm{H}$ plane \\
\hline [84] & $\begin{array}{l}\text { C-shaped } \\
\text { probe-fed } \\
\text { patch }\end{array}$ & PIN diode & 12.1 & LP & 1-B1T & 22.1 & 22.2 & $16 \%$ & $\pm 60^{\circ} \mathrm{E}$ and $\mathrm{H}$ plane \\
\hline$[85]$ & $\begin{array}{l}\text { split } \\
\text { circular } \\
\text { rings }\end{array}$ & PIN diode & 5 & LP & 1-B1T & 16.8 & 18.4 & $\begin{array}{c}17 \% \\
(1-\mathrm{dB})\end{array}$ & $\pm 40^{\circ} \mathrm{E}$ and $\mathrm{H}$ plane \\
\hline$[86]$ & $\begin{array}{l}\text { multilayer } \\
\text { annular } \\
\text { ring } \\
\text { patches }\end{array}$ & PIN diode & 14 & LP & 1-B1T & 20.4 & 33.4 & $33 \%$ & $\pm 50^{\circ} \mathrm{E}$ and $\mathrm{H}$ plane \\
\hline
\end{tabular}

This work is further improved in [84]: a $16 \times 16$ elements reconfigurable transmitarray is proposed in this paper. The transmitter is designed as a C-shape feed probe placed beneath a rectangular patch to obtain the feathers of broad bandwidth and lower insertion loss. The receiver of the transmitarray is a U-shaped slot etched on a simple rectangular patch. To induce a reverse current path, two PIN diodes are symmetrically placed on the feed probe of the unit cell shown in Figure 6. The minimum measured insertion loss is realized at $0.47 \mathrm{~dB}$ for each phase state with $16 \%$ of $3 \mathrm{~dB}$ broad bandwidth achieved by stepped impedance matching performance. There are 256 elements in the feed shape probe transmitarray with 512 PIN diodes used in its manufacturing and testing. The maximum peak gain is $22.1 \mathrm{dBi}$ at $12.5 \mathrm{GHz}$ with an aperture efficiency of $21.2 \%$. The $3 \mathrm{~dB}$ insertion bandwidth is realized at $12.3 \%$ with electronic beam scanning performance of \pm 60 degrees for two-dimensional H- and E-planes, respectively. This novel reconfigurable transmitarray is a good solution for many applications in wireless communication systems.

Another advanced technique structure of a transmitarray is reported in [85] with a polarization rotation unit cell. Two split circles are connected with two narrow strips with pin diodes mounted in between them. Polarization control structures sandwich the PIN diode loaded with a transmitter and receiver. The air gap is presented between the transmitter and receiver to mount diodes on patches easily, and bias circuits are etched on the polarization control structure. The phase difference $180^{\circ}$ is achieved for two outgoing polarized waves for 0 and 180 degree phase states. The polarization control structure reduces the blocking effect of dc-bias lines and improves the aperture efficiency of the structure. A $16 \times 16$ 1-bit transmitarray is designed, fabricated, and tested in a test setup. Two-dimensional electronic beams scanning of \pm 40 degrees is realized by the polarization rotation element. The maximum measure $3 \mathrm{~dB}$ and $1 \mathrm{~dB}$ insertion loss of $45 \%$ and $17 \%$ 
are obtained, respectively, at $5.5 \mathrm{GHz}$. The aperture efficiency of the polarization rotation transmitarray is $18.4 \%$.

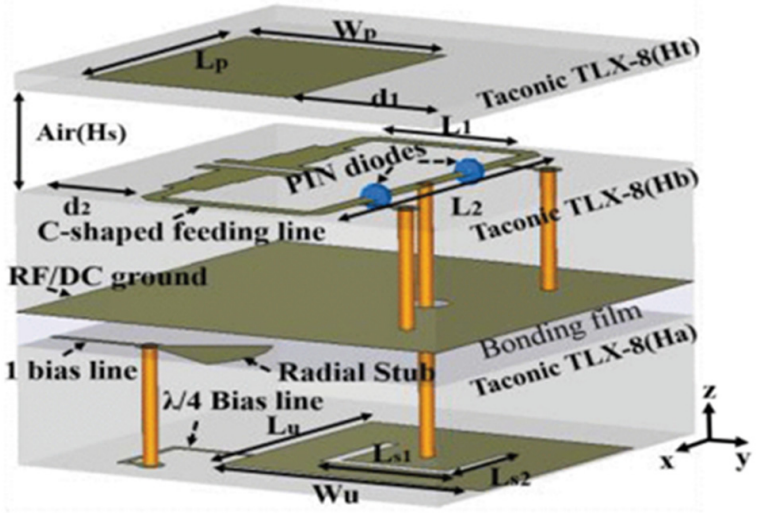

(a)

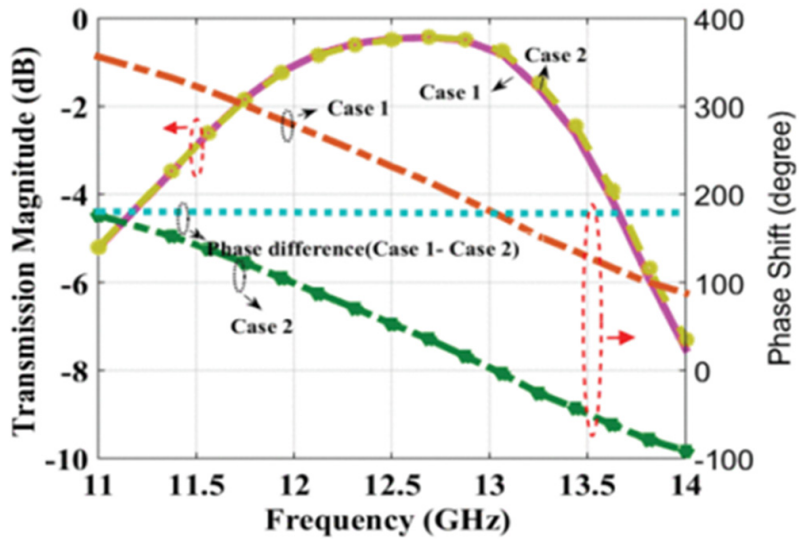

(b)

Figure 6. (a) Exploded view of the proposed unit cell; (b) simulated results of transmission magnitude and phase shift (reprinted with permission of [84]. Copyright 2020 Wang, M., et al.).

In [86], the authors have presented a $10 \times 10$ elements 1-bit reconfigurable transmitarray (RTA) with linear polarization at $\mathrm{Ku}$-band. This transmitarray has the ability of beam steering for a wide range of frequencies. The reported unit cell consists of multiple-layer circular rings and substrates. Every element of the RTA has the capability to electronically control phase shift path difference for 0 and 180 states. The $3 \mathrm{~dB}$ gain bandwidth of the structure lies at 33\% (12.5 GHz-17.5 GHz) at $15 \mathrm{GHz}$ frequency. The effective aperture efficiency of the annular rings RTA is achieved up to $33.64 \%$ at $15 \mathrm{GHz}$. From $14 \mathrm{GHz}$ to $17 \mathrm{GHz}$, two-dimensional beam steering with \pm 60 degrees may be realized.

\subsection{Varactor Diodes}

The literature review also presents the reconfigurable transmitarray (RTA) made up of varactors to accomplish beam forming/beam steering [87-92]. Varactor diodes are the best solution for continuous tuning by using electronic switches. Varactor diodes are mature technology; they are economical, have low insertion losses, can be modeled easily, and have voltage control switches. There are a wide range of diodes that can be used related to applications shown in Figure 7. It is important to choose the varactor diode that offers the best performance for many applications. A varactor diode capacitance ratio is defined as $\mathrm{C}_{\max } / \mathrm{C}_{\mathrm{in}}$, meaning a large capacitance ratio results in a wide range of tuning capacitance. There is a detail Summary of beam steering reconfigurable transmitarrays with varactor diodes shown in Table 2.

A varactor diode reconfigurable transmitarray (VD-RTA) is presented in [93,94] for beam steering performance. Each element of the transmitarray is composed of four substrate Rogger RO4350B double sided layers, shown in Figure 7. One pair can be tuned for $180^{\circ}$ phase shift control, and a whole pair of unit cells duplicated to earn $360^{\circ}$ phase shift. The electronic phase control of the element is obtained by loading each layer with varactor diodes. A theoretical $3 \mathrm{~dB}$ bandwidth of the unit cell is $1 \mathrm{GHz}$ at 24.6, as mentioned in this paper, but it reveals that the insertion loss of this paper achieves $-5 \mathrm{~dB}$. Experimental results show that $3 \mathrm{~dB}$ insertion losses are quite high up to $-12 \mathrm{~dB}$ for this transmitarray. Furthermore, this work is extended in [94] and an array of $6 \times 6$ elements of the abovementioned transmitarray is fabricated. This RTA has the experimental performance of beam scanning capability \pm 50 degrees at $24.6 \mathrm{GHz}$ in both the H-plane and E-plane. 


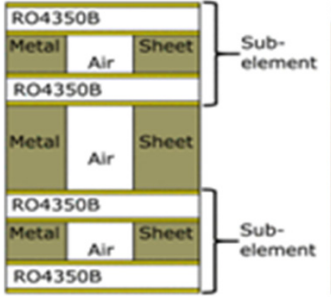

(a)

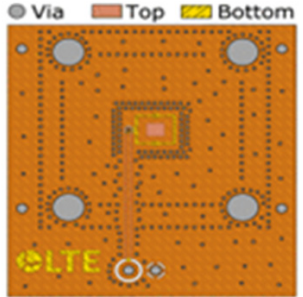

(b)

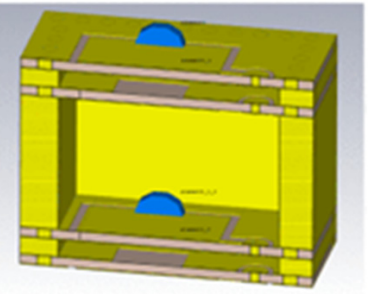

(c)

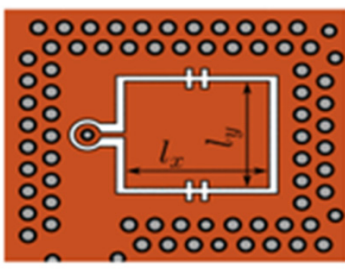

(d)

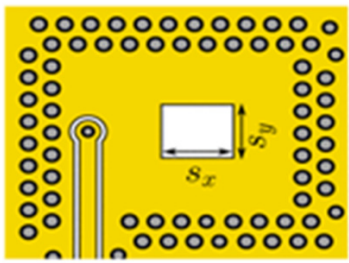

(e)

Figure 7. (a) Layer stack view of proposed unit cell, (b) layout view, (c) 3D view, (d) top layer, (e) bottom layer (reprinted with permission of [94]. Copyright 2019 Frank, M., et al.).

Another novel varactor diode and pin diode base phase shifter transmitarray design is reported in [95]. A wideband varactor diode and pin diode base phase shifter reconfigurable transmitter gives continuous phase shift control at $5.8 \mathrm{GHz}$. This multilayer element structure transmitter (Tx) comprises an $\mathrm{H}$-slot rectangular patch integrated with two diodes. A varactor diode is mounted on the receiver layer to build a $180^{\circ}$ analog phase shifter combined with pin diodes to acquire $360^{\circ}$ electronic phase shift. Theoretical transmission insertion loss includes $0.85 \mathrm{~dB}$ to $1.24 \mathrm{~dB}$ at $5.8 \mathrm{GHz}$ frequency. A $3 \mathrm{~dB}$ bandwidth is obtained up to $17 \%$ of the required frequency. A $16 \times 16$ elements prototype of the transmitarray is designed, fabricated, and measured result tested. A maximum peak gain of $23.7 \mathrm{dBi}$ at $5.8 \mathrm{GHz}$ is achieved using the varactor diode-based phase shifter transmitarray. The 2D transmitarray beam scanning performances are maintained for \pm 60 degrees elevation and azimuth planes.

In addition, a frequency selective surface (FSS) varactor diode reconfigurable transmitarray with 2D beam scanning ability is reported in [96]. Each layer of the FSS loaded with a varactor diode enables beam scanning of the main beam of the original radiation pattern in both the E-plane and H-plane. A five-layer $5 \times 5$ FSS transmitarray integrated with varactor diodes coupled with a horn antenna feed network has been verified with theoretical and experimental results. Two simulated and fabricated models are developed with a peak gain of $20.2 \mathrm{dBi}$ and $19.9 \mathrm{dBi}$, respectively, at $5.8 \mathrm{GHz}$ frequency. Experimental results of 2D beam steering are realized approximately \pm 30 degrees in both the azimuth and elevation planes. The proposed RTA shows the potential for use in applications with better economical fabrication cost compared to the most direct alternative beam steering approaches.

A detailed case study has been presented in [97] of the practical constraints of twodimensional beam steering using a varactor diode-based meta-material at micro and $\mathrm{mm}$ wave frequencies. The practical impacts of the varactor diode utilized with a meta-materialbased RTA are deeply observed, as shown in Figure 8. Various results of the internal resistance, capacitance, and inductance have been compared in the reported paper.

Four prototypes are developed on different frequencies, including 5, 14, 28, and $60 \mathrm{GHz}$, to understand the effect of internal resistance Rs and internal inductance Ls of varactor diodes. It is concluded from the above study that internal resistance Rs have various impacts on RTAs. On the other hand, internal inductance Ls affects the proposed TA's bandwidth and operational frequency band response. As internal inductance Ls increases, higher frequencies shift towards lower frequencies, increasing the bandwidth of the reported elements. These result in a reduction in the overall phase shift accomplished 
by multilayers of unit cells that may have the impact of reducing the scanning range of TAs to perform beam steering with a transmitarray.

Table 2. Summary of beam steering reconfigurable transmitarrays with varactor diodes.

\begin{tabular}{|c|c|c|c|c|c|c|c|c|c|}
\hline Ref & $\begin{array}{l}\text { Unit Cell } \\
\text { Technique }\end{array}$ & $\begin{array}{l}\text { Phase } \\
\text { Control } \\
\text { Device }\end{array}$ & $\begin{array}{l}\text { Frequency } \\
\text { (GHz) }\end{array}$ & Polarization & $\begin{array}{l}\text { Phase } \\
\text { Range }\end{array}$ & $\begin{array}{l}\text { Gain } \\
\text { (dBi) }\end{array}$ & $\begin{array}{l}\text { Aperture } \\
\text { Efficiency }\end{array}$ & $\begin{array}{l}\text { Band } \\
\text { Width }\end{array}$ & $\begin{array}{c}\text { Beam Steering } \\
\text { Capacity }\end{array}$ \\
\hline [94] & stacked layers & $\begin{array}{l}\text { varactor } \\
\text { diode }\end{array}$ & 24.6 & $\mathrm{LP}$ & $360^{\circ}$ & - & - & $1 \mathrm{GHz}$ & $\pm 50^{\circ} \mathrm{E}$ and $\mathrm{H}$ plane \\
\hline [95] & $\begin{array}{c}\text { compact } \\
\text { varactor based } \\
\text { phase shifters }\end{array}$ & $\begin{array}{l}\text { varactor } \\
\text { diode }\end{array}$ & 5.6 & LP & $\begin{array}{l}360^{\circ} \\
1-\mathrm{BIT}\end{array}$ & 15.7 & 33.3 & $16.7 \%$ & $60^{\circ} \mathrm{E}$ and $\mathrm{H}$ plane \\
\hline [96] & FSS & $\begin{array}{l}\text { varactor } \\
\text { diode }\end{array}$ & 5.2 & LP & $480^{\circ}$ & 20.2 & - & $13 \%$ & $\pm 30^{\circ} \mathrm{E}$ and $\mathrm{H}$ plane \\
\hline [98] & $\begin{array}{l}\text { integrated } \\
\text { leaky wave }\end{array}$ & $\begin{array}{l}\text { varactor } \\
\text { diode }\end{array}$ & 4.8 & LP & $400^{\circ}$ & 15.6 & 34 & $9 \%$ & $\pm 45^{\circ} \mathrm{E}$ and $\mathrm{H}$ plane \\
\hline
\end{tabular}

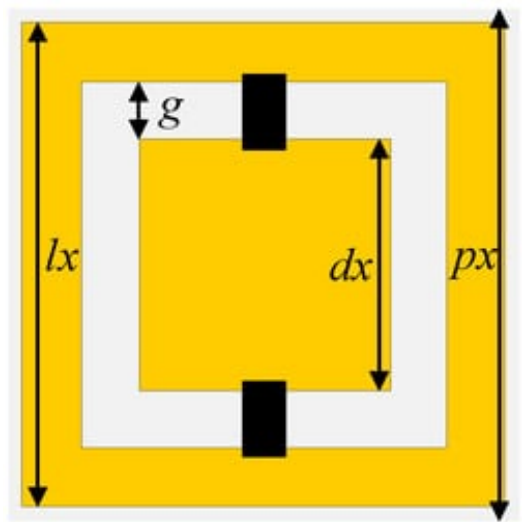

(a)

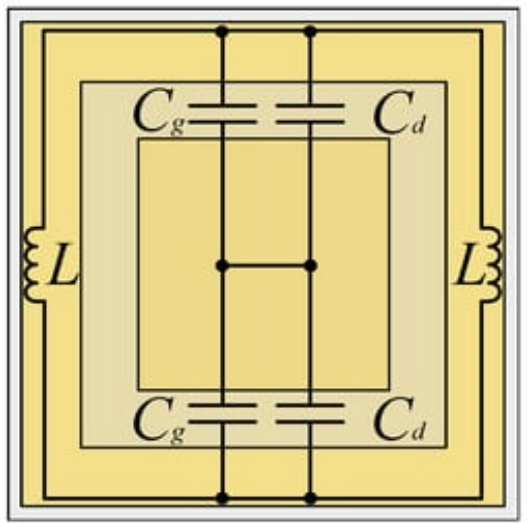

(b)

Figure 8. (a) FSS proposed unit cell; (b) equivalent circuit diagram (reprinted with permission of [97]. Copyright 2021 Reis, J.R., et al.).

\subsection{MEMS Switches}

In the past decade, dynamic progress and development have been seen for reconfigurable devices in antenna and array applications. In radar and communications system applications, reconfigurable components' demand has increased day by day due to the multi-functionality and versatile adaptability of array systems. As a result, emerging technologies (such as MEMS) have been developed, and innovative solutions have recently been introduced. MEMS are an excellent solution to realize beam forming/beam steering characteristics in reconfigurable transmitarrays (RTAs). A detail Summary of beam steering reconfigurable transmitarrays with MEMS in Table 3.

These are miniature elements of structure created with semiconductor technology. They have remarkable advantages over other reconfigurable devices, such as being small in size, low power usage, and high-level integration. Several MEMS switches reconfigurable transmitarrays have been reported in [98-104] the literature for beam steering. 
Table 3. Summary of beam steering reconfigurable transmitarrays with MEMS.

\begin{tabular}{|c|c|c|c|c|c|c|c|c|c|}
\hline Ref & $\begin{array}{l}\text { Unit Cell } \\
\text { Technique }\end{array}$ & $\begin{array}{l}\text { Phase } \\
\text { Control } \\
\text { Device }\end{array}$ & $\begin{array}{l}\text { Frequency } \\
\text { (GHz) }\end{array}$ & Polarization & $\begin{array}{l}\text { Phase } \\
\text { Range }\end{array}$ & Gain & $\begin{array}{l}\text { Aperture } \\
\text { Efficiency }\end{array}$ & $\begin{array}{l}\text { Band } \\
\text { Width }\end{array}$ & $\begin{array}{c}\text { Beam Scanning } \\
\text { Capacity }\end{array}$ \\
\hline$[100]$ & FSS & MEMS & 30.2 & $\mathrm{CP}$ & $360^{\circ}$ & - & - & $\begin{array}{l}1.6 \mathrm{GHz} \\
(1 \mathrm{~dB})\end{array}$ & - \\
\hline [103] & $\begin{array}{c}\text { antenna filter } \\
\text { antenna }\end{array}$ & MEMS & 32 & LP & 2-bit & 26.5 & - & - & $\pm 60^{\circ} \mathrm{E}$ and $\mathrm{H}$ plane \\
\hline$[104]$ & $\begin{array}{l}\text { antenna filter } \\
\text { antenna }\end{array}$ & MEMS & 34.8 & LP & 2-bit & 9.6 & 6.2 & - & $\pm 40^{\circ} \mathrm{E}$ and $\mathrm{H}$ plane \\
\hline
\end{tabular}

A convenient 1-bit reconfigurable transmitarray (RTA) unit cell for X-band applications was demonstrated in [34]. A four-metal layer unit cell with two identical substrates was used in the proposed unit cell. The O-slot patch acts as a transmitter (Tx), and U-slot patch behaves as a receiver $(\mathrm{Rx})$ etched on $\mathrm{RO} 4003$ substrate connected with a metal probe. The electronic phase shift control is obtained by MEMS switches with series bias via two bias lines printed on the substrates. The proposed element retains low insertion losses of $0.8 \mathrm{~dB}$ and wide $3 \mathrm{~dB}$ bandwidth of $16 \%$. A bandpass filter reconfigurable frequency selective surface (FSS) was reported in [100] using MEMS switches, as shown in Figure 9. A four-legged bridge was mounted with RF-MEMS switches and DC-bias lines to control the ON/OFF mechanism of the switches. There are 909 elements and 3636 RF-MEMS switch bridges integrated to control the phase shift for the beam steering of the array. MEMS switches FSS transmitarray elements gain $3.2 \mathrm{GHz}, 3 \mathrm{~dB}$ bandwidth at $30 \mathrm{GHz}$, and $99.9 \%$ accuracy is achieved during the experimental test verified for the proposed array.

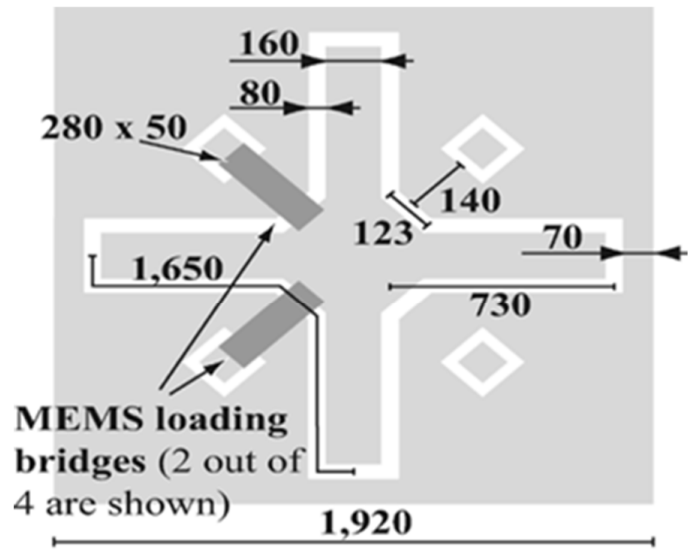

(a)

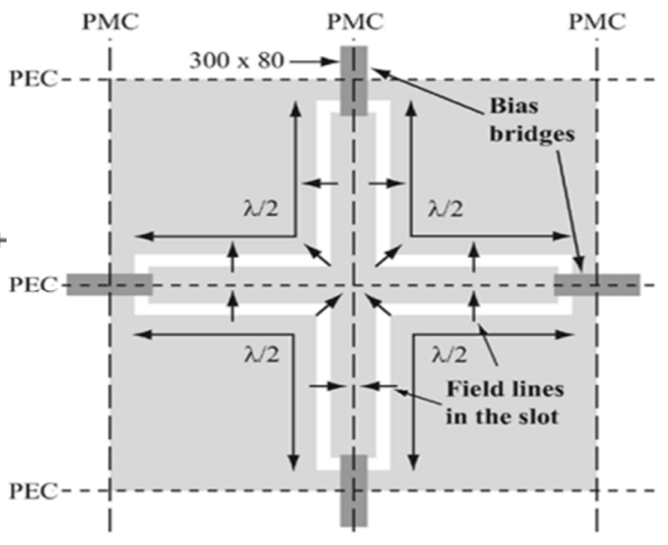

(b)

Figure 9. (a) Proposed unit cell with MEMS bridge; (b) unit cell with bias bridge (reprinted with permission of [100]. Copyright 2004 Schoenlinner, B., et al.).

A 2-bit programmable MEMS, antenna filter antenna (AFA), and millimeter-wave frequency reconfigurable lens-array are presented in [104]. A AFA lens-Array integrated with 1021 switches was fabricated on two quartz wafer substrates. It consisted of three metal layers, bound with an adhesive and integrated with two orthogonally oriented slots. This array explores various characteristics of design, fabrication, and test performance. A 2-bit programmable MEMS switches mechanism provides four possible states of phase shifts, including $0^{\circ}, 90^{\circ}, 180^{\circ}$, and $270^{\circ}$. Moreover, the 2-bit phase resolution reduces the directivity of the transmitarray due to phase quantization loss. The proposed prototype shows an insertion loss that includes $1.4 \mathrm{~dB}$ to $1.6 \mathrm{~dB}$ for different phase states. AFA 2D beam scanning realized \pm 60 degrees for the azimuth and elevation planes at $32 \mathrm{GHz}$. 


\subsection{Microfluids}

In the modern era, adaptability and versatility are fascinating characteristics of advanced communication systems. Microfluids have exotic parameters, flexible flow properties, and acquiescent elastic limits, and are mechanically flexible compared to copper or other metallic materials. These feathers are also helpful for innovative fabrication technologies such as 3D antennas, spraying antennas, and fluid conductive antennas. Compared to traditional high speed switching methods, beam steering reconfigurable antennas function with the reconfigurability of microfluid liquids related to electronic pumping and electro-mechanically controlled capillaries. Several articles for reconfigurable microfluid transmitarray beam steering are demonstrated in the preceding literature [105-108]. Additionally, a circularly polarized microfluid-based transmitarray antenna unit cell is reported in [108]. The reconfigurable unit cell was manufactured with two split rings slots produced so that microfluid can pass through this channel, as shown in Figure 10. Microfluid passes through these split slot channels to obtain control on the phase shift beam steering. Microfluid circulates through the symmetric circular rings of elements and rotates through the circular slots causing liquid displacement to be controlled and the phase shift to double the rotation angle. The circulation of microfluid passing through the circular rings delivers continuous 0-360 degrees of phase shift. A microfluid transmitarray prototype is manufactured at glass substrate, and a slot channel is etched by Polydimethyl-siloxane (PDMS) at $8.8 \mathrm{GHz}$ frequency. The expected insertion loss includes $2-3 \mathrm{~dB}$, reaching up to $1 \mathrm{~dB}$ liquid rotation. The proposed element insertion losses become remarkably high $-10 \mathrm{~dB}$ with testation of waveguide characteristic setup. On the contrary, it takes time to reconfigure itself in the active mode, which reduces its effectiveness for applications. Each unit cell acquires many slot tubes to circulate microfluid inside the elements to gain reconfigurable characteristics. This feature will lead to an increase in the unit cell sizes to utilize the slot tubes.

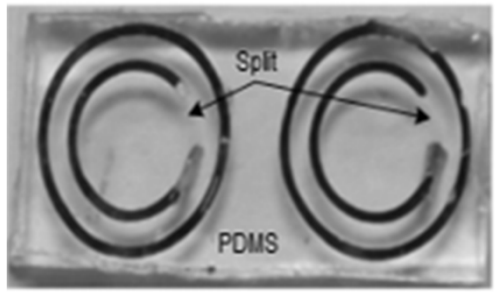

(a)

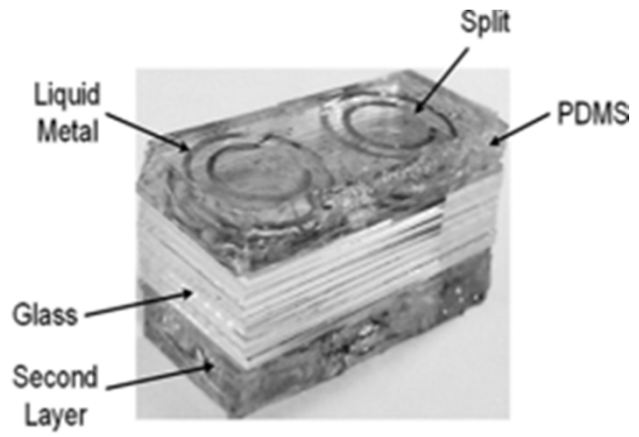

(b)

Figure 10. (a) Top view of unit cell; (b) nested ring split ring prototype (reprinted with permission of [109]. Copyright 2015 Erdil, E., et al.).

Moreover, a plasma reconfigurable transmitarray/reflectarray antenna is introduced in [109]. The radiating incident waves with a source feed antenna are placed in different directions. A $13 \times 13$ elements array composed of 169 elements with reconfigurable plasma as a transmitarray/reflectarray antenna is demonstrated. The reflectarray antenna mode is exhibited due to the plasma ground plane acting as a perfect conductor and collision frequency of atoms $1 \mathrm{THz}$. Contrarily, when the plasma ground plane is not ionized, it behaves as a dielectric material to perform the transmitarray antenna mode. The phase shift of the array is controlled by argon gas density injected into symmetrical unit cells. Each element consists of a two cylindrical tubes setup on the top and bottom and a ground plate filled with argon $\left(\mathrm{Ar}_{\mathrm{g}}\right)$ gas. DC-bias voltage is applied to the end of the cylinder. The frequency of plasma argon gas $\left(\mathrm{Ar}_{\mathrm{g}}\right)$ is varied, leading to variation in the reflection coefficient from 0-305 degrees corresponding to the maximum reflection coefficient that reaches up to $-8 \mathrm{~dB}$. The continuous transmission phase shift control 
executes from 0-345 degrees. Moreover, the remaining phase control compensates due to plasma frequency variation. Plasma transmitarray/reflectarray is accomplished with a 2D beam scanning ability of \pm 30 degrees for the H-plane and E-Plane at $19.75 \mathrm{GHz}$ and $19.39 \mathrm{GHz}$, respectively.

\section{Beam Steering/Beam Forming Using Variable Source Antenna}

The beam steering is acquired by changing the position of the primary feed source or using an electronically variable source antenna. To enhance the performance of beam steering, the concept of multi-focal transmitarray is introduced. Generally, two identical feed sources are placed where the phase error becomes minimal. The focal point is 33 degrees for a beam direction provided in bifocal transmitarray. There are some studies reported in the literature that demonstrate beam steering using variable source antennas. The early investigation of variable source antenna beam steering is demonstrated in [110,111]. Reference [47] presents a beam steering transmission antenna using an electrically variable source antenna. A novel variable source beam scanning transmitarray presents as shown in Figure 11. There is a $3 \mathrm{D}$ dielectric printing transmitarray illustrated on paper with a taper section to enhance the bandwidth of the transmitarray. A $50 \times 50$ elements transmitarray with variable source beam scanning capabilities and wide bandwidth transmitarray is validated with measured and experimental results. The measured radiation performance shows $1 \mathrm{~dB}$ bandwidth over $23 \%$ achieved at $30 \mathrm{GHz}$. The radiation performance of \pm 27 degrees is obtained in the E-plane at $30 \mathrm{GHz}$ with variable source mechanisms.

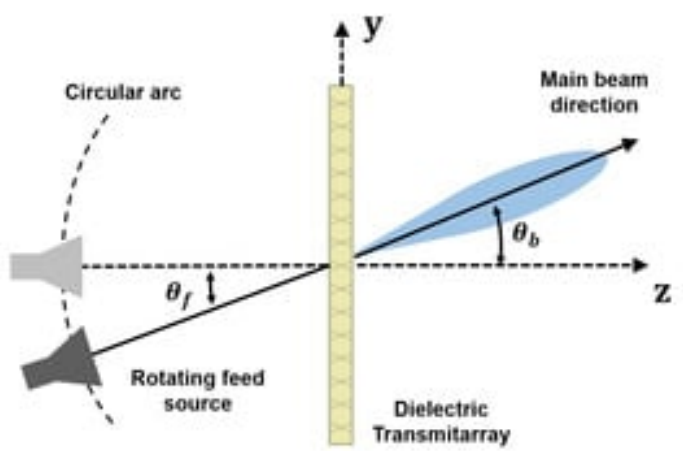

(a)

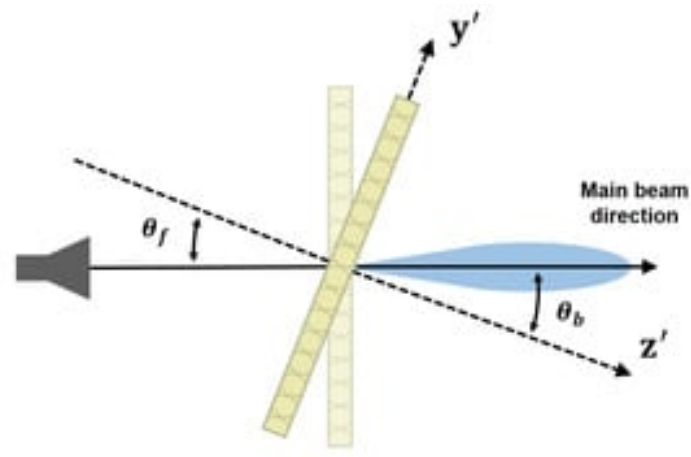

(b)

Figure 11. (a) Proposed mechanism of beam scanning transmitarray; (b) actual implementation of variable source transmitarray (reprinted with permission of [47]. Copyright 2019 Massaccesi, A., et al.).

There is a method to steer the beam by the structurally fixed transmitarray and the switching of the source antenna. Since the wavefront of the source antenna is variable, as described in Figure $3 a$ the beam steering transmission antenna is realized by the combination with the transmission phase of the transmitarray. Five source antennas are selectively operated by applying two SP3T switching elements. Although the beam steering characteristics can be implemented relatively simply, there are also disadvantages of a limited beam steering angle and discretization. To improve such a drawback, a study was conducted to realize a continuous beam steering angle by operating two source antennas and adjusting the position and of each phase [48]. The combination of a two-dimensional metasurface and a planar source antenna capable of one dimensional phase control improves the gain of the existing one dimensional phased array antenna.

Moreover, an automotive radar application of a dual-layer $77 \mathrm{GHz}$ printed circuit board transmitarray is presented [49]. There are four SIW antennas used as the primary feed source. Coplanar unit cells are linked with vias and printed on the opposite side of the PCB. The coplanar unit cell was designed with concentric rings to gain a 1-bit phase shift of the transmitarray. Four substrate integrated waveguides were used as source antennas to obtain four beams to obtain a beam scanning range over \pm 15 degrees throughout the 
desired bandwidth. The transmitarray generates $18.5 \mathrm{~dB}$ of gain at $76.5 \mathrm{GHz}$, with good agreement in theoretical and experimental results. Alternatively, in [112], an optically transparent transmitarray is presented with a focal source (horn antenna) replaced with a $2 \times 2$ unit cells aperture couple stack microstrip patch antenna of a seven element array as shown in Figure 12. Beam steering is obtained by switching the position of seven $2 \times 2$ arrays to the next one. The choice of an aperture couple stack microstrip patch array over a horn antenna creates the transparent transmitarray's low profile and light weight. The proposed meshed double ring unit cells achieve a reduced transmission loss and slight dependence on the angle of incidence at the Ka-band. The unit cells contribute to a phase shift of $300^{\circ}$ with $1 \mathrm{~dB}$ reduced insertion loss at $28.5 \mathrm{GHz}$. Theoretical and measured results exhibit beam-wide scanning angles attaining \pm 30 degrees in the azimuth plane at $28.5 \mathrm{GHz}$. The maximum gain of the transparent transmitarray is $19.5 \mathrm{dBi}$, corresponding to the minimum SLL <-12.4 dB, ranging from $27.5 \mathrm{GHz}$ to $29.5 \mathrm{GHz}$. This work is a remarkable candidate for reducing the visual impact for $5 \mathrm{G}$ communication systems and smart beam steering technology.

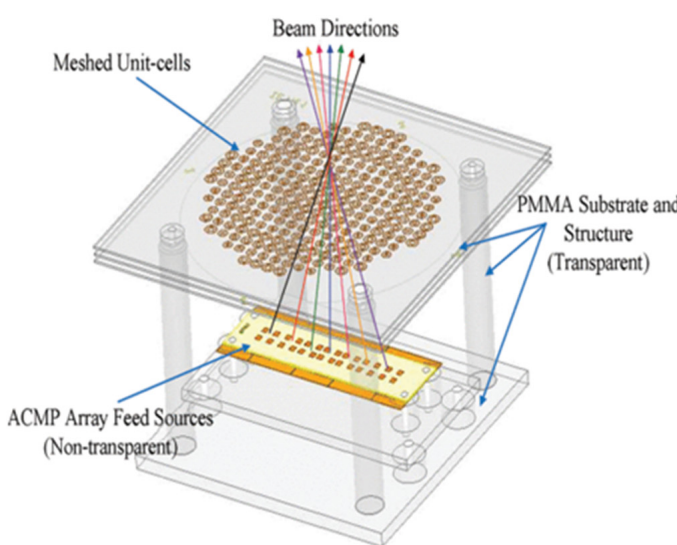

(a)

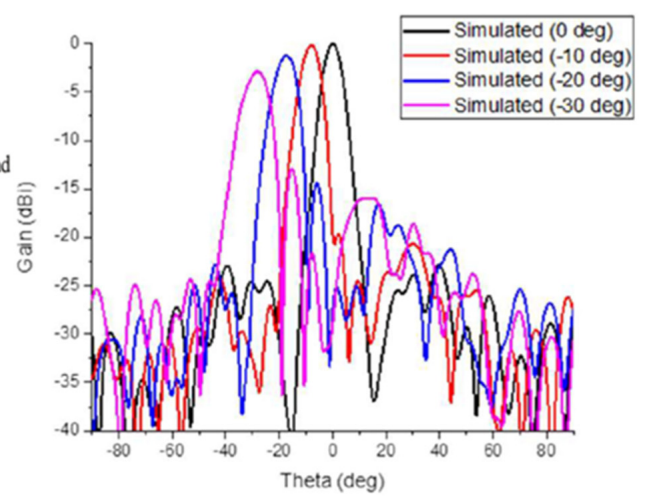

(b)

Figure 12. (a) Simulated transmitarray with ACMP feed source; (b) gain pattern with variable source feeds. (reprinted with permission of [112]. Copyright 2019 Liu, G., et al.).

A planar multi-focal source transmitarray antenna beam scanning performance is explored in [113]. The proposed planar multi-focal transmitarray antenna pros are described in this article over the traditional transmitarray. A quad-focal phase shift distribution was studied by applying the particle swarm optimization technique for \pm 60 degrees beam scanning range for $\mathrm{Ku}$-band transmitarray. The findings of this study show that a multi-focal transmitarray antenna can be an excellent low-cost option for high gain beam forming applications. In normal conditions, multi-focal transmitarray constraints give an extra degree of freedom that cannot be achieved without variations in the lattice geometry or transmitarray curvature. However, the phase error can be addressed by optimizing the array aperture phase distribution mechanism. At $14.5 \mathrm{GHz}$, a $260 \mathrm{~mm}$ aperture diameter with $\mathrm{F} / \mathrm{D}$ equal to 1 is built to exhibit quad-focal transmitarray. The azimuth plane \pm 60 degrees beam scanning performance is examined. This phenomenon shows exceptional beam scanning accomplishment for a quad-focal transmitarray.

\section{Future Challenges and Scope}

Transmitarray technology has become mature in the last decade. Many research articles are available in the literature to demonstrate the fixed and reconfigurable beam transmitarray discussed in the previous sections. There are still gaps available to explore new characteristics in this area, in particular, for reconfigurable technology. Here, this section discusses different future aspects and challenges related to future technologies. The discussion is focused on the future of terahertz and optical frequencies for this technology, dual-band reconfigurable transmitarrays, and multi-bits transmitarrays. 


\subsection{Terahertz and Optical Frequencies}

Terahertz and optical frequency bands ranging from $100 \mathrm{GHz}$ to $3 \mathrm{THz}$ have potential for next generation wireless communication with a vast scope of applications due to the lack of use and unexplored spectrum. For instance, a circularly polarized graphene-based transmitarray for $6 \mathrm{THz}$ is explored in [38]. Another sub-THz anisotropic fixed-configuration three-layer transmitarray is investigated in [114]. A fixed beam wideband high efficient transmitarray for D-band is studied in [115]. The implementation of reconfigurable $\mathrm{THz}$ and optical frequencies has many challenges ahead. The working principles of $\mathrm{THz}$ and above frequencies are similar to millimeter and microwave frequencies to design a transmitarray. Reflectarrays and transmitarrays provide the concept of low insertion losses and simple electronic beam control solutions. The most prominent challenge is the fabrication of higher frequency switchable and other devices. Mostly, conductors, dielectric materials, and polymers are lossy and economical to manufacture for higher frequencies.

Beam control terahertz and optical frequency transmitarrays become a potential candidate for many applications of the terahertz spectrum, such as wireless cognition, sensing, imaging, etc. An effort ha been put into terahertz MEMS switches for a reconfigurable reflectarray at $120 \mathrm{GHz}$ frequency [116]. However, MEMS switches are electrically large elements that can easily be loaded with the array. In particular, reconfigurable materials-based technologies should be considered. Some research articles have investigated liquid crystals, particularly graphene-based cells topology. Therefore, beam scanning reconfigurable transmitarrays realization at terahertz and optical frequencies represents a fascinating frontier in which technological challenges are likely to play a far more significant role than in lower frequency applications.

\subsection{Multi-Bit Structures}

To reduce 1-bit reconfigurable transmitarray phase quantization insertion loss, several designs were investigated for a 2-bit or 3-bit fixed beam (passive) transmitarray [117-119]. A multi-bit phase quantization transmitarray significantly improves execution for collimating characteristics over a 1-bit structure. The most important design principle for a transmitarray is insertion loss and phase quantization of the structure elements, in particular for beam steering (using reconfigurable electronic techniques). High phase quantization improves the directivity, aperture efficiency, and side lobe levels of the transmitarray. In an ideal case, a complete $360^{\circ}$ phase shift and high phase quantization are required to achieve high directivity and low side lobe levels. Multi-bit phase quantization for electronically reconfigurable transmitarray still has challenges. A large number of solid-state devices, bias network complications, bandwidth, and power ingestion are compared to a 1-bit transmitarray. Using a 2-bit reconfigurable transmitarray can improve 30-40\% aperture efficiency, as indicated in [120]. Only one paper on a 2-bit electronically reconfigurable MEMS system is available [103]. Briefly, this structure consists of wafer technology with five MEMS with bias lines, and six independent bias lines to control the complex biasing network. Due to its complexity, size, and other structures, no attempt for multi-phase quantization has been performed yet for RF-MEMS switches. In [103], it is suggested that structure significantly affects high switching resistance and insertion losses of around 4.2-9.4 dB. Moreover, novel 2-bit electronically reconfigurable transmitarray experimental results have been demonstrated in [27] for Ka-band. This unit cell is fabricated with dimensions $\lambda / 2 \times \lambda / 2 \times \lambda / 8$ at $29.5 \mathrm{GHz}$ with six metal layers and three substrate layers. Four switches using PIN diodes are integrated on unit cells to achieve a 2-bit phase resolution of a reconfigurable transmitarray. An increase in the number of diodes from 2 to 4 produces an effect on insertion losses; the maximum measured insertion losses reach up to $2.03 \mathrm{~dB}$, corresponding to the minimum insertion loss to any stage $1.39 \mathrm{~dB}$ at $29.5 \mathrm{GHz}$. This is a remarkable effort compared to the MEMS-based unit cell. This work is further extended in [75] to convert observed unit cells into a $14 \times 14$ reconfigurable array. The proposed unit cell array obtains $19.8 \mathrm{~dB}$ gain with $15.9 \%$ of aperture efficiency at $29.5 \mathrm{GHz}$ for 2-bit resolution. A multi-bit electronically reconfigurable transmitarray has a significant gap for future research, particularly for a higher frequency. There is no reconfigurable phase quantization research 
updated with liquid crystal or microfluid at high frequency. Extending this technique to other configurations may be a practical way forward in the future for realizing high gain reconfigurable apertures.

\subsection{Dual-Band Frequency}

Dual-band transmitarray design is a remarkable challenge to obtain complete $\pm 360^{\circ}$ transmission phase shift and insertion loss close to $0 \mathrm{~dB}$ in both frequency bands. We need to attain both parameters to gain optimal features of the dual-band frequencies. Dual-polarization is another significant parameter for satellite communication applications. Independent phase shift for a dual-band transmitarray becomes a more difficult task due to dual-polarization. For satellite communication applications, lower and higher band frequencies in the Ku-band $(12.5 / 14.5)$ are close to each other for satellite communication applications. Resonance peaks are very close to each other, so this proximity impacts both transmission magnitude and the phase of dual-band frequencies. The fact that few investigations have been conducted on dual-bands is a challenge. In addition, numerous fixed beam dual-band structures have been studied in the literature [121-123]. It is noted that much less work has been carried out to investigate reconfigurable dual-band unit cells. The proposed unit cell is based on MMIC Technology for $\mathrm{K} / \mathrm{Ka}$-band active transmitarray, as reported in [121]. This paper is the first reconfigurable dual-band SiGe-BICMOS MMIC-based transmitarray design, fabricated and tested. For instance, applications for satellite communication two-way data-links acquire from $19.7 \mathrm{GHz}$ to $21 \mathrm{GHz}$ downlinks and 29.5 to 30.8 for uplinks. Electronically reconfigurable dual-band is a promising gap for future research for many applications such as satellite communication (Sat-Com) and $6 \mathrm{G} / 5 \mathrm{G}$ cellular systems with all of its challenging problems. This electronically reconfigurable dual-band transmitarray also has the potential to facilitate revolutionary applications, which will be enabled by new thinking and developments in solid-state devices, applications, and systems. A detail Summary of beam steering methods with characteristics to conclude out whole work, see Table 4.

Table 4. Summary of beam steering methods with characteristics.

\begin{tabular}{|c|c|c|c|c|}
\hline Ref. & $\begin{array}{l}\text { Beam } \\
\text { Steering } \\
\text { Method }\end{array}$ & $\begin{array}{c}\text { Control } \\
\text { Elements/Devices }\end{array}$ & Advantages & Disadvantages \\
\hline [74-78] & \multirow{9}{*}{$\begin{array}{c}\text { Active } \\
\text { Transmitarray }\end{array}$} & PIN diodes & $\begin{array}{l}\text { Broadband transmission and differential } \\
\text { phase shift characteristics }\end{array}$ & $\begin{array}{l}\text { Complexity of design due to } \\
\text { half via for biasing }\end{array}$ \\
\hline$[82,83]$ & & PIN diodes & $\begin{array}{l}\text { Coupling Slots TA, large-angle beam } \\
\text { scanning capability }\end{array}$ & $\begin{array}{l}\text { Results are not symmetric } \\
\text { through out the obtain } \\
\text { frequency }\end{array}$ \\
\hline [84] & & PIN diodes & $\begin{array}{l}\text { Excellent beam steering performance } \\
\text { but the degradation of antenna } \\
\text { efficiency }\end{array}$ & $\begin{array}{l}\text { The degradation of antenna } \\
\text { efficiency }\end{array}$ \\
\hline$[90,91]$ & & Varactor diodes & $\begin{array}{l}\text { Excellent beam steering performance, } \\
\text { but complicated bias circuit }\end{array}$ & complicated bias circuit \\
\hline [93] & & Varactor diodes & $\begin{array}{l}\text { High gain, simple circuitry, narrow } \\
\text { beam scanning }\end{array}$ & narrow beam scanning \\
\hline [94] & & Varactor diodes & $\begin{array}{l}\text { Parametric study of the unit cell, more } \\
\text { stack unit cell high internal resistance }\end{array}$ & $\begin{array}{l}\text { more stack unit cell high } \\
\text { internal resistance }\end{array}$ \\
\hline$[100]$ & & MEMS & 2 bit phase quantization, directivity loss & $\begin{array}{l}\text { High insertion loss, } \\
\text { directivity loss }\end{array}$ \\
\hline [105] & & MEMS & $\begin{array}{l}\text { High insertion loss, poor power } \\
\text { efficiency }\end{array}$ & $\begin{array}{l}\text { High insertion loss, poor } \\
\text { power efficiency }\end{array}$ \\
\hline [109] & & Microfluids & Narrow beam steering angle & Narrow beam steering angle \\
\hline [112] & \multirow{2}{*}{$\begin{array}{l}\text { Variable } \\
\text { Source } \\
\text { Transmitarray }\end{array}$} & $\begin{array}{l}\text { Seven } 2 \times 2 \text { aperture } \\
\text { couple source } \\
\text { antenna }\end{array}$ & $\begin{array}{l}\text { Reduce visual impact important for 5G } \\
\text { and small cell steering }\end{array}$ & Discrete beam steering angle \\
\hline [113] & & multi-focal source & $\begin{array}{l}\text { Excellent beam steering performance, } \\
\text { quad-focal phase shift distribution }\end{array}$ & Multiple focal source \\
\hline
\end{tabular}




\section{Conclusions}

Combining a planar array with a variable transmission phase change with a fixed source antenna or a metasurface with a fixed transmission phase change and a source antenna with a variable wavefront shape yields the beam steering characteristics of the transmitarray antenna. This article intends to provide a quick overview to readers on recent developments and challenges on beam steering characteristics for transmitarray antennas. It explains the operation of beam forming/beam steering transmitarrays and various types of beam steering structures investigated along with their radiation characteristics. In addition, to secure the maximum aperture efficiency of the transmission antenna, it is necessary to calculate the optimal F/D according to the gain of the source antenna and design a metasurface with high transmission efficiency. Multiple electronic reconfigurable devices and components are demonstrated for the beam steering/beam forming characteristics of the reconfigurable transmitarray. A comprehensive overview of recently reported work in this regard is presented. This article also outlined the future demands and challenges that will make beam steering transmitarrays even more attractive as future prospects for various applications.

Author Contributions: All the authors have contributed to this paper. Q.A., X.B. and I.A. researched, discussed, and wrote the manuscript. W.S., S.S. and S.M.A. revised the manuscript. S.M.A. and H.S. supervised and administrated the research work. All authors have read and agreed to the published version of the manuscript.

Funding: National Natural Science Foundation of China under Contract 62071037 are with the Beijing Key Laboratory of Millimeter-Wave and Terahertz Wave Technology, School of Integrated Circuits and Electronics, Beijing Institute of Technology, Beijing 100081, China.

Conflicts of Interest: The authors declare no conflict of interest.

\section{References}

1. Alibakhshikenari, M.; Virdee, B.S.; See, C.H.; Abd-Alhameed, R.A.; Falcone, F.; Limiti, E. High-Isolation Leaky-Wave Array Antenna Based on CRLH-Metamaterial Implemented on SIW with $\pm 30^{\circ}$ Frequency Beam-Scanning Capability at MillimetreWaves. Electronics 2019, 8, 642. [CrossRef]

2. Alibakhshikenari, M.; Virdee, B.S.; Khalily, M.; Shukla, P.; See, C.H.; Abd-Alhameed, R.; Falcone, F.; Limiti, E. Beam-scanning leaky-wave antenna based on CRLH-metamaterial for millimetre-wave applications. IET Microw. Antennas Propag. 2019, 13, 1129-1133. [CrossRef]

3. Alibakhshi-Kenari, M.; Andújar, A.; Anguera, J. New compact printed leaky-wave antenna with beam steering. Microw. Opt. Technol. Lett. 2016, 58, 215-217. [CrossRef]

4. Bia, P.; Caratelli, D.; Mescia, L.; Gielis, J. Analysis and synthesis of supershaped dielectric lens antennas. IET Microw. Antennas Propag. 2015, 9, 1497-1504. [CrossRef]

5. Hwang, S.; Lee, B.; Kim, D.H.; Park, J.Y. Design of S-band phased array antenna with high isolation using broadside coupled split ring resonator. J. Electromagn. Eng. Sci. 2018, 18, 108-116. [CrossRef]

6. Rudge, A.; Adatia, N. New class of primary-feed antennas for use with offset parabolic-reflector antennas. Electron. Lett. 1975, 11, 597-599. [CrossRef]

7. Kock, W. Path-length microwave lenses. Proc. IRE 1949, 37, 852-855. [CrossRef]

8. McGrath, D. Planar three-dimensional constrained lenses. IEEE Trans. Antennas Propag. 1986, 34, 46-50. [CrossRef]

9. Pozar, D. Flat lens antenna concept using aperture coupled microstrip patches. Electron. Lett. 1996, 32, 2109-2111. [CrossRef]

10. Liu, X.; Peng, L.; Liu, Y.F.; Yu, W.S.; Zhao, Q.X.; Jiang, X.; Li, S.M.; Ruan, C. Ultrabroadband All-Dielectric Transmitarray Designing Based on Genetic Algorithm Optimization and 3-D Print Technology. IEEE Trans. Antennas Propag. 2020, 69, 2003-2012. [CrossRef]

11. Afzal, M.U.; Esselle, K.P.; Lalbakhsh, A. A Methodology to Design a Low-Profile Composite-Dielectric Phase-Correcting Structure. IEEE Antennas Wirel. Propag. Lett. 2018, 17, 1223-1227. [CrossRef]

12. Yu, W.-S.; Peng, L.; Liu, Y.-F.; Zhao, Q.-X.; Jiang, X.; Li, S.M. An Ultra-wideband and High Aperture Efficiency All-Dielectric Lens Antenna. IEEE Antennas Wirel. Propag. Lett. 2021, 20, 2442-2446. [CrossRef]

13. Godi, G.; Sauleau, R.; Le Coq, L.; Thouroude, D. Design and Optimization of Three-Dimensional Integrated Lens Antennas with Genetic Algorithm. IEEE Trans. Antennas Propag. 2007, 55, 770-775. [CrossRef]

14. Fan, Y.; Xu, Y.; Qiu, M.; Jin, W.; Zhang, L.; Lam, E.; Tsai, D.; Lei, D. Phase-controlled metasurface design via optimized genetic algorithm. Nanophotonics 2020, 9, 3931-3939. [CrossRef]

15. Zhao, X.; Yuan, C.; Liu, L.; Peng, S.; Qiang, Z.; Zhou, H. All-Metal Transmit-array for Circular Polarization Design Using Rotated Cross-Slot Elements for High Power Microwave Applications. IEEE Trans. Antennas Propag. 2017, 65, 3253-3256. [CrossRef] 
16. Chen, G.T.; Jiao, Y.C.; Zhao, G. Novel wideband metal-only transmitarray antenna based on 1-bit polarization rotation element. Int. J. RF Microw. Comput.-Aided Eng. 2020, 30, e22388. [CrossRef]

17. Abdelrahman, A.H.; Elsherbeni, A.Z.; Yang, F. Transmitarray antenna design using cross-slot elements with no dielectric substrate IEEE Antennas Wirel. Propag. Lett. 2014, 13, 177-180. [CrossRef]

18. Zhao, J.; Li, T.; Li, H.; Yang, X.; Zhou, Y.; Mao, W.; Wang, H.; Hu, B.; Zou, H.; Liu, Q. A Novel Planar Mode-Transducing Antenna Based on Metal-Only Transmitarray Surfaces. IEEE Trans. Antennas Propag. 2019, 67, 3762-3773. [CrossRef]

19. Liu, G.; Wang, H.J.; Jiang, J.S.; Xue, F.; Yi, M.A. high-efficiency transmitarray antenna using double split ring slot elements. IEEE Antennas Wirel. Propag. Lett. 2015, 14, 1415-1418. [CrossRef]

20. Guerra, A.; Guidi, F.; Clemente, A.; D'Errico, R.; Dussopt, L.; Dardari, D. Application of transmitarray antennas for indoor mapping at millimeter-waves. In Proceedings of the 2015 European Conference on Networks and Communications (EuCNC), Paris, France, 29 June-2 July 2015; IEEE: Piscataway, NJ, USA, 2015.

21. Santini, T.; Zhao, Y.; Wood, S.; Krishnamurthy, N.; Kim, J.; Farhat, N.; Alkhateeb, S.; Martins, T.; Koo, M.; Zhao, T.; et al. In-vivo and numerical analysis of the eigenmodes produced by a multi-level Tic-Tac-Toe head transmit array for 7 Tesla MRI. PLoS ONE 2018, 13, e0206127. [CrossRef]

22. Rappaport, T.S.; Sun, S.; Mayzus, R.; Zhao, H.; Azar, Y.; Wang, K.; Wong, G.; Schulz, J.K.; Samimi, M.; Gutierrez, F. Millimeter Wave Mobile Communications for 5G Cellular: It Will Work! IEEE Access 2013, 1, 335-349. [CrossRef]

23. Jouanlanne, C.; Clemente, A.; Huchard, M.; Keignart, J.; Barbier, C.; Le Nadan, T.; Petit, L. Wideband Linearly Polarized Transmitarray Antenna for $60 \mathrm{GHz}$ Backhauling. IEEE Trans. Antennas Propag. 2017, 65, 1440-1445. [CrossRef]

24. Zainud-Deen, S.H.; Hassan, W.; Malhat, H. Near-Field focused folded transmitarray antenna for medical applications. Wirel. Pers. Commun. 2017, 96, 4885-4894. [CrossRef]

25. Hassanien, A.; Vorobyov, S.A.; Yoon, Y.S.; Park, J.Y. Root-MUSIC based source localization using transmit array interpolation in MIMO radar with arbitrary planar arrays. In Proceedings of the 2013 5th IEEE International Workshop on Computational Advances in Multi-Sensor Adaptive Processing (CAMSAP), Saint Martin, France, 15-18 December 2013; IEEE: Piscataway, NJ, USA, 2013

26. Veljovic, M.J.; Skrivervik, A.K. Circularly Polarized Transmitarray Antenna for CubeSat Intersatellite Links in K-Band. IEEE Antennas Wirel. Propag. Lett. 2020, 19, 1749-1753. [CrossRef]

27. Chen, Q.; Saifullah, Y.; Yang, G.-M.; Jin, Y.-Q. Electronically reconfigurable unit cell for transmit-reflect-arrays in the X-band. Opt. Express 2021, 29, 1470-1480. [CrossRef]

28. Li, W.; Wang, Y.; Sun, S.; Shi, X. An FSS-Backed Reflection/Transmission Reconfigurable Array Antenna. IEEE Access 2020, 8 , 23904-23911. [CrossRef]

29. Reis, J.; Al-Daher, R.Z.; Copner, N.; Caldeirinha, R.; Fernandes, T. Two-dimensional antenna beamsteering using metamaterial transmitarray. In Proceedings of the 2015 9th European Conference on Antennas and Propagation (EuCAP), Lisbon, Portugal, 12-17 April 2015; IEEE: Piscataway, NJ, USA, 2015.

30. Ali, Q.; Xiao, Y.; Sun, H. 1 BIT Wide-Band Hexagonal Electronically Reconfigurable Unit Cell for Ka-Band Transmit-array. In Proceedings of the 2020 IEEE Asia-Pacific Microwave Conference (APMC), Hong Kong, China, 8-11 December 2020; IEEE: Piscataway, NJ, USA, 2020.

31. Tang, J.; Xu, S.; Yang, F.; Li, M. Design of a Wideband Reconfigurable Transmitarrray Element Using a Novel Phase Shifter with Varactors and PIN Diodes. In Proceedings of the 2019 International Symposium on Antennas and Propagation (ISAP), Xi'an, China, 27-30 October 2019; IEEE: Piscataway, NJ, USA, 2019.

32. Ali, Q.; Xiao, Y.; Bin, X.; Sun, H.J. 1 BIT Fractal Hexagonal Shape Electronically Reconfigurable Transmit-array Unit Cell for 5G Communication Systems. In Proceedings of the 2021 1st International Conference on Microwave, Antennas \& Circuits (ICMAC), Islamabad, Pakistan, 21-22 December 2021.

33. Huang, C.; Pan, W.; Ma, X.; Zhao, B.; Cui, J.; Luo, X. Using Reconfigurable Transmitarray to Achieve Beam-Steering and Polarization Manipulation Applications. IEEE Trans. Antennas Propag. 2015, 63, 4801-4810. [CrossRef]

34. Clemente, A.; Dussopt, L.; Reig, B.; Sauleau, R.; Potier, P.; Pouliguen, P. 1-bit mems based reconfigurable unit-cell for transmitarray antennas at $x$-band frequencies. In Proceedings of the 13th International Symposium on RF MEMS and RF Microsystems (MEMSWAVE 2012), Antalya, Turkey, 2-4 July 2012.

35. Perez-Palomino, G.; Carrasco, E.; Cano-Garcia, M.; Hervas, R.; Quintana, X.; Geday, M.A. Design and Evaluation of Liquid Crystal-Based Pixels for Millimeter and Sub-Millimeter Electrically Addressable Spatial Wave Modulators. In Proceedings of the 2019 International Conference on Electromagnetics in Advanced Applications (ICEAA), Granada, Spain, 9-13 September 2019. [CrossRef]

36. Li, X.; Li, Z.; Wan, C.; Song, S. Design and Analysis of Terahertz Transmitarray Using 1-bit Liquid Crystal Phase Shifter. In Proceedings of the 2020 9th Asia-Pacific Conference on Antennas and Propagation (APCAP), Xiamen, China, 4-7 August 2020; IEEE: Piscataway, NJ, USA, 2020.

37. Long, S.A.; Huff, G.H. A fluidic loading mechanism for phase reconfigurable reflectarray elements. IEEE Antennas Wirel. Propag. Lett. 2011, 10, 876-879. [CrossRef]

38. Malhat, H.A.; Zainud-Deen, S.H.; Gaber, S.M. Circularly polarized graphene based transmitarray for terahertz applications. In Proceedings of the 2014 XXXIth URSI General Assembly and Scientific Symposium (URSI GASS), Beijing, China, 16-23 August 2014; IEEE: Piscataway, NJ, USA, 2014. 
39. Manzillo, F.F.; Smierzchalski, M.; Reverdy, J.; Clemente, A.A. Ka-band Beam-Steering Transmitarray Achieving Dual-Circular Polarization. In Proceedings of the 2021 15th European Conference on Antennas and Propagation (EuCAP), Online, 22-26 March 2021; IEEE: Piscataway, NJ, USA, 2021.

40. Clemente, A. Deliverable D3. 2: Electronically Reconfigurable Antenna; European Commission: Brussels, Belgium, 2017.

41. Minatti, G.; Martini, E.; Caminita, F.; Pavone, S.C.; Albani, M.; Toso, G.; Maci, S. Electronically reconfigurable metasurface antennas based on liquid crystal technology. In Proceedings of the 2019 13th European Conference on Antennas and Propagation (EuCAP), Krakow, Poland, 31 March-5 April 2019; IEEE: Piscataway, NJ, USA, 2019.

42. Hu, W.; Dickie, R.; Cahill, R.; Gamble, H.; Ismail, Y.; Fusco, V.; Linton, D.; Grant, N.; Rea, S. Liquid Crystal Tunable mm Wave Frequency Selective Surface. IEEE Microw. Wirel. Components Lett. 2007, 17, 667-669. [CrossRef]

43. Hassan, W.M. Multilayer graphene-only transmitarray antenna (MGOT) for terahertz applications. In Proceedings of the 2017 34th National Radio Science Conference (NRSC), Alexandria, Egypt, 13-16 March 2017. [CrossRef]

44. Lima, E.B.; Matos, S.A.; Costa, J.R.; Fernandes, C.A.; Fonseca, N.J.G. Circular Polarization Wide-Angle Beam Steering at Ka-Band by In-Plane Translation of a Plate Lens Antenna. IEEE Trans. Antennas Propag. 2015, 63, 5443-5455. [CrossRef]

45. Rahmati, B.; Hassani, H.R. Low-Profile Slot Transmitarray Antenna. IEEE Trans. Antennas Propag. 2014, 63, 174-181. [CrossRef]

46. Jiang, M.; Chen, Z.N.; Zhang, Y.; Hong, W.; Xuan, X. Metamaterial-Based Thin Planar Lens Antenna for Spatial Beamforming and Multibeam Massive MIMO. IEEE Trans. Antennas Propag. 2016, 65, 464-472. [CrossRef]

47. Massaccesi, A.; Dassano, G.; Pirinoli, P. Beam scanning capabilities of a 3d-printed perforated dielectric transmitarray. Electronics 2019, 8, 379. [CrossRef]

48. Lee, J.G.; Kwon, T.S.; Lee, J.H. Beam pattern reconfigurable circularly polarized transmitarray antenna by rearrangement of sources. Microw. Opt. Technol. Lett. 2019, 61, 999-1003. [CrossRef]

49. Yeap, S.B.; Qing, X.; Chen, Z.N. 77-GHz dual-layer transmit-array for automotive radar applications. IEEE Trans. Antennas Propag. 2015, 63, 2833-2837. [CrossRef]

50. Tuloti, S.H.R.; Rezaei, P.; Hamedani, F.T. High-efficient wideband transmitarray antenna. IEEE Antennas Wirel. Propag. Lett. 2018, 17, 817-820. [CrossRef]

51. Bagheri, M.O.; Hassani, H.R.; Rahmati, B. Dual-band, dual-polarised metallic slot transmitarray antenna. IET Microw. Antennas Propag. 2017, 11, 402-409. [CrossRef]

52. Chen, L.-W.; Ge, Y.; Bird, T.S. Ultrathin flat microwave transmitarray antenna for dual-polarised operations. Electron. Lett. 2016, 52, 1653-1654. [CrossRef]

53. Tian, C.; Jiao, Y.-C.; Zhao, G. Circularly polarized transmitarray antenna using low-profile dual-linearly polarized elements. IEEE Antennas Wirel. Propag. Lett. 2016, 16, 465-468. [CrossRef]

54. Xu, H.X.; Cai, T.; Zhuang, Y.Q.; Peng, Q.; Wang, G.M.; Liang, J.G. Dual-mode transmissive metasurface and its applications in multibeam transmitarray. IEEE Trans. Antennas Propag. 2017, 65, 1797-1806. [CrossRef]

55. Abdelrahman, A.H.; Nayeri, P.; Elsherbeni, A.Z.; Yang, F. Single-Feed Quad-Beam Transmitarray Antenna Design. IEEE Trans. Antennas Propag. 2016, 64, 953-959. [CrossRef]

56. Lee, C.; Hoang, T.V.; Chi, S.W.; Lee, S.; Lee, J. Low profile quad-beam circularly polarised antenna using transmissive metasurface IET Microw. Antennas Propag. 2019, 13, 1690-1698. [CrossRef]

57. Mailloux, R.J. Phased Array Antenna Handbook; Artech House: Norwood, MA, USA, 2017.

58. Reis, J.; Al-Daher, Z.; Copner, N.; Hammoudeh, A.; Caldeirinha, R.; Fernandes, T. Two-dimensional transmitarray beamsteering using stacked tunable metamaterials. In Proceedings of the 2014 Loughborough Antennas and Propagation Conference (LAPC), Loughborough, UK, 10-11 November 2014; IEEE: Piscataway, NJ, USA, 2014.

59. Abdelrahman, A.H.; Nayeri, P.; Elsherbeni, A.Z.; Yang, F. Analysis and Design of Transmitarray Antennas. Synthesis Lectures on Antennas; Morgan \& Claypool: San Rafael, CA, USA, 2017; Volume 6, pp. 1-175.

60. Diaby, F.; Clemente, A.; Dussopt, L.; Sauleau, R.; Pham, K.; Fourn, E. Design of a 3-facet linearly-polarized transmitarray antenna at Ka-band. In Proceedings of the 2018 IEEE International Symposium on Antennas and Propagation \& USNC/URSI National Radio Science Meeting, Boston, MA, USA, 8-13 July 2018; IEEE: Piscataway, NJ, USA, 2018.

61. Rana, B.; Lee, I.G.; Hong, I.P. Digitally reconfigurable transmitarray with beam-steering and polarization switching capabilities. IEEE Access 2021, 9, 144140-144148. [CrossRef]

62. Pozar, D.M.; Targonski, S.D.; Syrigos, H. Design of millimeter wave microstrip reflectarrays. IEEE Trans. Antennas Propag. 1997, 45, 287-296. [CrossRef]

63. Niu, T.; Withayachumnankul, W.; Ung, B.; Menekse, H.; Bhaskaran, M.; Sriram, S.; Fumeaux, C. Experimental demonstration of reflectarray antennas at terahertz frequencies. Opt. Express 2013, 21, 2875-2889. [CrossRef]

64. Adamidis, G.; Vardiambasis, I. Design and Implementation of a $4 \times 4$ Butler-Matrix Switched-Beam Antenna Array at the Microwave Communications and Electromagnetic Applications Lab of the Technological Educational Institute of Crete. In Proceedings of the 2005 WSEAS International Conference on Engineering Education (EE'05), Athens, Greece, 8-10 July 2005 pp. 374-379.

65. Adamidis, G.; Vardiambasis, I. Smart antenna design and implementation: A simple switched-beam antenna array based on a $8 \times 8$ Butler-matrix network. In Proceedings of the 10th WSEAS International Conference on Communications, Athens, Greece, 13-15 July 2006; WSEAS: Stevens Point, WI, USA, 2006. 
66. Adamidis, G.A.; Vardiambasis, I.O.; Ioannidou, M.P.; Kapetanakis, T.N. Design and implementation of single-layer $4 \times 4$ and $8 \times 8$ Butler matrices for multibeam antenna arrays. Int. J. Antennas Propag. 2019, 2019, 1645281. [CrossRef]

67. Capolino, F. Applications of Metamaterials; CRC Press: Boca Raton, FL, USA, 2017.

68. Balanis, C.A. Advanced Engineering Electromagnetics; John Wiley \& Sons: Hoboken, NJ, USA, 2012.

69. Munk, B.A. Frequency Selective Surfaces: Theory and Design; John Wiley \& Sons: Hoboken, NJ, USA, 2005.

70. Sarabandi, K.; Behdad, N. A frequency selective surface with miniaturized elements. IEEE Trans. Antennas Propag. 2007, 55, 1239-1245. [CrossRef]

71. Li, M.N.B. Wideband true-time-delay microwave lenses based on metallo-dielectric and all-dielectric lowpass frequency selective surfaces. IEEE Trans. Antennas Propag. 2013, 61, 4109-4119. [CrossRef]

72. Warren Stutzman, L.; Thiele, G.A. Antenna Theory and Design; John Wiley \& Sons: Hoboken, NJ, USA, 2012.

73. Clemente, A.; Diaby, F.; Di Palma, L.; Dussopt, L.; Sauleau, R. Experimental validation of a 2-bit reconfigurable unit-cell for transmitarrays at Ka-band. IEEE Access 2020, 8, 114991-114997. [CrossRef]

74. Di Palma, L.A.C.; Dussopt, L.; Sauleau, R.; Potier, P.; Pouliguen, P. Circularly-polarized reconfigurable transmitarray in Ka-band with beam scanning and polarization switching capabilities. IEEE Trans. Antennas Propag. 2017, 65, 529-540. [CrossRef]

75. Diaby, F.; Clemente, A.; Sauleau, R.; Pham, K.T.; Dussopt, L. 2 Bit Reconfigurable Unit-Cell and Electronically Steerable Transmitarray at Ka-Band. IEEE Trans. Antennas Propag. 2019, 68, 5003-5008. [CrossRef]

76. Xiao, Y.; Yang, F.; Xu, S.; Li, M.; Zhu, K.; Sun, H. Design and Implementation of a Wideband 1-Bit Transmitarray Based on a Yagi-Vivaldi Unit Cell. IEEE Trans. Antennas Propag. 2021, 69, 4229-4234. [CrossRef]

77. Xiao, Y.; Xi, B.; Xiang, M.; Yang, F.; Chen, Z. 1-Bit Wideband Reconfigurable Transmitarray Unit Cell Based on PIN Diodes in Ku-Band. IEEE Antennas Wirel. Propag. Lett. 2021, 20, 1908-1912. [CrossRef]

78. Wang, Y.; Xu, S.; Yang, F.; Werner, D.H. 1 Bit Dual-Linear Polarized Reconfigurable Transmitarray Antenna Using Asymmetric Dipole Elements with Parasitic Bypass Dipoles. IEEE Trans. Antennas Propag. 2020, 69, 1188-1192. [CrossRef]

79. Wang, M.; Mo, Y.; Chen, Z.; Shan, K.; Liu, Z.; Feng, J.; Liu, Q.; Li, J. Design of A $4 \times$ 4-Element High-Integrated Planar Pattern Reconfigurable Array Antenna. In Proceedings of the 2021 15th European Conference on Antennas and Propagation (EuCAP), Online, 22-26 March 2021; IEEE: Piscataway, NJ, USA, 2021.

80. Kozlov, D.; Munina, I.; Turalchuk, P.; Kirillov, V.; Shitvov, A.; Zelenchuk, D. Characterization of Tiled Architecture for C-Band 1-Bit Beam-Steering Transmitarray. Sensors 2021, 21, 1259. [CrossRef]

81. Turalchuk, P.; Munina, I.; Kirillov, V.; Verevkin, A.; Zelenchuk, D. A C-band Transmitarray for Spatial Multiplexing and Diversity Applications. In Proceedings of the 2020 50th European Microwave Conference (EuMC), Utrecht, The Netherlands, 12-14 January 2021. [CrossRef]

82. Munina, I.; Turalchuk, P.; Verevkin, A.; Kirillov, V.; Zelenchuk, D.; Shitvov, A. A study of C-band 1-bit reconfigurable dualpolarized transmitarray. In Proceedings of the 2019 13th European Conference on Antennas and Propagation (EuCAP), Krakow, Poland, 31 March-5 April 2019; IEEE: Piscataway, NJ, USA, 2019.

83. Wang, M.; Xu, S.; Yang, F.; Li, M. Design and Measurement of a 1-bit Reconfigurable Transmitarray With Subwavelength H-Shaped Coupling Slot Elements. IEEE Trans. Antennas Propag. 2019, 67, 3500-3504. [CrossRef]

84. Wang, M.; Xu, S.; Yang, F.; Hu, N.; Xie, W.; Chen, Z. A Novel 1-Bit Reconfigurable Transmitarray Antenna Using a C-Shaped Probe-Fed Patch Element with Broadened Bandwidth and Enhanced Efficiency. IEEE Access 2020, 8, 120124-120133. [CrossRef]

85. Luo, C.-W.; Zhao, G.; Jiao, Y.-C.; Chen, G.-T.; Yan, Y.-D. Wideband 1 bit Reconfigurable Transmitarray Antenna Based on Polarization Rotation Element. IEEE Antennas Wirel. Propag. Lett. 2021, 20, 798-802. [CrossRef]

86. Zhai, Z.; Zhao, G.; Sun, H. Design of a Wideband 1-bit $10 \times 10$ Reconfigurable Transmitarray in Ku Band. In Proceedings of the 2020 International Conference on Microwave and Millimeter Wave Technology (ICMMT), Shanghai, China, 20-23 September 2020; IEEE: Piscataway, NJ, USA, 2020.

87. Lau, J.Y.; Hum, S.V. Analysis and characterization of a multipole reconfigurable transmitarray element. IEEE Trans. Antennas Propag. 2010, 59, 70-79. [CrossRef]

88. Rotshild, D.; Rahamim, E.; Abramovich, A. Innovative Reconfigurable Metasurface 2-D Beam-Steerable Reflector for 5G Wireless Communication. Electronics 2020, 9, 1191. [CrossRef]

89. Sun, Y.; Li, Z.; Zhu, W.; Ji, Z.; Wang, Q. New steerable antenna with controllable metamaterial. In Proceedings of the 20129 th European Radar Conference, Amsterdam, The Netherlands, 31 October-2 November 2012; IEEE: Piscataway, NJ, USA, 2012.

90. Jiang, T.; Wang, Z.; Li, D.; Pan, J.; Zhang, B.; Huangfu, J.; Salamin, Y.; Li, C.; Ran, L. Low-DC voltage-controlled steering-antenna radome utilizing tunable active metamaterial. IEEE Trans. Microw. Theory Tech. 2011, 60, 170-178. [CrossRef]

91. Russo, I.; Gaetano, D.; Boccia, L.; Amendola, G.; Di Massa, G. Investigation on the transmission beam-steering capabilities of tunable impedance surfaces. In Proceedings of the 2009 European Microwave Conference (EuMC), Rome, Italy, 29 September-1 October 2009; IEEE: Piscataway, NJ, USA, 2009.

92. Padilla, P.; Muñoz-Acevedo, A.; Castañer, M.S.; Sierra-Pérez, M. Electronically Reconfigurable Transmitarray at Ku Band for Microwave Applications. IEEE Trans. Antennas Propag. 2010, 58, 2571-2579. [CrossRef]

93. Frank, M.; Weigel, R.; Koelpin, A. Design of a $24 \mathrm{GHz}$ reconfigurable transmitarray element with continuous phase range. In Proceedings of the 2017 11th European Conference on Antennas and Propagation (EUCAP), Paris, France, 19-24 March 2017; IEEE: Piscataway, NJ, USA, 2017. 
94. Frank, M.; Lurz, F.; Weigel, R.; Koelpin, A. Electronically reconfigurable $6 \times 6$ element transmitarray at K-band based on unit cells with continuous phase range. IEEE Antennas Wirel. Propag. Lett. 2019, 18, 796-800. [CrossRef]

95. Tang, J.; Xu, S.; Yang, F.; Li, M. Design and Measurement of a Reconfigurable Transmitarray Antenna with Compact Varactor-based Phase Shifters. IEEE Antennas Wirel. Propag. Lett. 2021, 20, 1998-2002. [CrossRef]

96. Reis, J.R.; Caldeirinha, R.F.S.; Hammoudeh, A.; Copner, N. Electronically reconfigurable FSS-inspired transmitarray for 2-D beamsteering. IEEE Trans. Antennas Propag. 2017, 65, 4880-4885. [CrossRef]

97. Reis, J.R.; Vala, M.; Oliveira, T.E.; Fernandes, T.R.; Caldeirinha, R.F.S. Metamaterial-Inspired Flat Beamsteering Antenna for 5G Base Stations at 3.6 GHz. Sensors 2021, 21, 8116. [CrossRef]

98. Nicholls, J.G.; Hum, S.V. Full-space electronic beam-steering transmitarray. IEEE Trans. Antennas Propag. 2016, 64, 3410-3422. [CrossRef]

99. Zendejas, J.M.; Gianvittorio, J.P.; Rahmat-Samii, Y.; Judy, J.W. Magnetic MEMS reconfigurable frequency-selective surfaces. J. Microelectromech. Syst. 2006, 15, 613-623. [CrossRef]

100. Schoenlinner, B.; Abbaspour-Tamijani, A.; Kempel, L.C.; Rebeiz, G.M. Switchable low-loss RF MEMS Ka-band frequency-selective surface. IEEE Trans. Microw. Theory Tech. 2004, 52, 2474-2481. [CrossRef]

101. Stephan, K.D.; Spooner, F.H.; Goldsmith, P.F. Quasioptical millimeter-wave hybrid and monolithic PIN diode switches. IEEE Trans. Microw. Theory Tech. 1993, 41, 1791-1798. [CrossRef]

102. Clemente, A.; Dussopt, L.; Sauleau, R.; Potier, P.; Pouliguen, P. 1-Bit Reconfigurable Unit Cell Based on PIN Diodes for TransmitArray Applications in X -Band. IEEE Trans. Antennas Propag. 2012, 60, 2260-2269. [CrossRef]

103. Cheng, C.-C.; Lakshminarayanan, B.; Abbaspour-Tamijani, A. A programmable lens-array antenna with monolithically integrated MEMS switches. IEEE Trans. Microw. Theory Tech. 2009, 57, 1874-1884. [CrossRef]

104. Cheng, C.-C.; Abbaspour-Tamijani, A. Study of 2-bit Antenna-Filter-Antenna Elements for Reconfigurable Millimeter-Wave Lens Arrays. IEEE Trans. Microw. Theory Tech. 2006, 54, 4498-4506. [CrossRef]

105. Guan, D.-F.; You, P.; Zhang, Q.; Xiao, K.; Yong, S.-W. Hybrid spoof surface plasmon polariton and substrate integrated waveguide transmission line and its application in filter. IEEE Trans. Microw. Theory Tech. 2017, 65, 4925-4932. [CrossRef]

106. Zainud-Deen, S.H.; Mabrouk, A.M.; Malhat, H.A.E.-A. Terahertz graphene based metamaterial transmitarray. Wirel. Pers. Commun. 2018, 100, 1235-1248. [CrossRef]

107. Zainud-Deen, S.; Malhat, H.; Mabrouk, A. Graphene based metamaterial lens for terahertz applications. In Proceedings of the 2017 Japan-Africa Conference on Electronics, Communications and Computers (JAC-ECC), Alexandria, Egypt, 18-20 December 2017; IEEE: Piscataway, NJ, USA, 2017.

108. Malhat, H.A.; Badawy, M.M.; Zainud-Deen, S.H.; Awadalla, K.H. Plasma reflectarray/transmitarray antennas using a single structure. Plasmonics 2015, 10, 1479-1487. [CrossRef]

109. Erdil, E.; Topalli, K.; Esmaeilzad, N.S.; Zorlu, Ö.; Kulah, H.; Civi, O.A. Reconfigurable nested ring-split ring transmitarray unit cell employing the element rotation method by microfluidics. IEEE Trans. Antennas Propag. 2015, 63, 1163-1167. [CrossRef]

110. Rotman, W.; Turner, R. Wide-angle microwave lens for line source applications. IEEE Trans. Antennas Propag. 1963, 11, 623-632. [CrossRef]

111. Rao, J. Multifocal three-dimensional bootlace lenses. IEEE Trans. Antennas Propag. 1982, 30, 1050-1056. [CrossRef]

112. Liu, G.; Kodnoeih, M.R.D.; Pham, K.T.; Cruz, E.M.; Ovejero, D.G.; Sauleau, R.; Pham, T.K. A millimeter-wave multibeam transparent transmitarray antenna at Ka-band. IEEE Antennas Wirel. Propag. Lett. 2019, 18, 631-635. [CrossRef]

113. Nayeri, P.; Yang, F.; Elsherbeni, A.Z. Design of multi-focal transmitarray antennas for beamforming applications. In Proceedings of the 2013 IEEE Antennas and Propagation Society International Symposium (APSURSI), Orlando, FL, USA, 7-13 July 2013; IEEE: Piscataway, NJ, USA, 2013.

114. Koutsos, O.; Manzillo, F.F.; Clemente, A.; Sauleau, R. Analysis and Efficient Design of Sub-THz Transmitarrays with Three Anisotropic Layers. In Proceedings of the 2021 15th European Conference on Antennas and Propagation (EuCAP), Online, 22-26 March 2021; IEEE: Piscataway, NJ, USA, 2021.

115. Saleh, W.; Letestu, Y.; Sauleau, R.; Cruz, E.M. Design and Measurements of a High-Performance Wideband Transmitarray Antenna for D-band Communications. IEEE Antennas Wirel. Propag. Lett. 2021, 20, 1765-1769. [CrossRef]

116. Tamminen, A.; Ala-Laurinaho, J.; Gomes-Martins, D.; Häkli, J.; Koivisto, P.; Kärkkäinen, M.; Mäkelä, S.; Pursula, P.; Rantakari, P.; Sipilä, M.; et al. Reflectarray for 120-GHz beam steering application: Design, simulations, and measurements. In Passive and Active Millimeter-Wave Imaging XV; International Society for Optics and Photonics: Bellingham, DC, USA, 2012.

117. Kaouach, H.; Dussopt, L.; Sauleau, R.; Koleck, T. Design and demonstration of 1-bit and 2-bit transmit-arrays at X-band frequencies. In Proceedings of the 2009 European Microwave Conference (EuMC), Rome, Italy, 29 September-1 October 2009; IEEE: Piscataway, NJ, USA, 2009.

118. Clemente, A.; Dussopt, L.; Sauleau, R.; Potier, P.; Pouliguen, P. Design and characterization of 2-bit passive unit-cells and transmit-arrays in X-band. In Proceedings of the 5th European Conference on Antennas and Propagation (EUCAP), Rome, Italy, 11-15 April 2011; IEEE: Piscataway, NJ, USA, 2011.

119. Vorobyov, A.; Fourn, E.; Sauleau, R.; Baghchehsaraei, Z.; Oberhammer, J.; Chicherin, D.; Räisänen, A. Iris-based 2-bit waveguide phase shifters and transmit-array for automotive radar applications. In Proceedings of the 20126 th European Conference on Antennas and Propagation (EUCAP), Prague, Czech Republic, 26-30 March 2012; IEEE: Piscataway, NJ, USA, 2012. 
120. Diaby, F.; Clemente, A.; Di Palma, L.; Dussopt, L.; Pham, K.; Fourn, E.; Sauleau, R. Design of a 2-bit unit-cell for electronically reconfigurable transmitarrays at Ka-band. In Proceedings of the 2017 47th European Microwave Conference (EuMC), Nuremberg, Germany, 10-12 October 2017; IEEE: Piscataway, NJ, USA, 2017.

121. Chaloun, T.; Hillebrand, C.; Waldschmidt, C.; Menzel, W. Active transmitarray submodule for K/Ka band satcom applications. In Proceedings of the 2015 German Microwave Conference, Nuremberg, Germany, 16-18 March 2015; IEEE: Piscataway, NJ, USA, 2015.

122. Pham, K.T.; Clemente, A.; Blanco, D.; Sauleau, R. Dual-Circularly Polarized High-Gain Transmitarray Antennas at Ka-Band. IEEE Trans. Antennas Propag. 2020, 68, 7223-7227. [CrossRef]

123. Pham, T.K.; Guang, L.; Gonzalez-Ovejero, D.; Sauleau, R. Dual-Band Transmitarray with Low Scan Loss for Satcom Applications. IEEE Trans. Antennas Propag. 2020, 69, 1775-1780. [CrossRef] 